\title{
Weed control under conservation agriculture in dryland smallholder farming systems of southern Africa. A review
}

\author{
Nicole Lee $\mathrm{e}^{1,2}$ (D) Christian Thierfelder ${ }^{3}$
}

Accepted: 28 August 2017 /Published online: 2 October 2017

(C) INRA and Springer-Verlag France SAS 2017

\begin{abstract}
Human-induced soil degradation has led to declining yields and soil fertility in many parts of the world. Conservation agriculture has been proposed as a strategy to ensure more sustainable land use. While conservation agriculture, based on minimum soil disturbance, crop residue retention, and diversification may improve a range of soil characteristics and can be a potential cropping system for improving farmer resilience to climate change, increased weed pressure is often an impediment to its widespread adoption in southern Africa. Weed control under conservation agriculture in other countries has been linked to increased herbicide use, but concerns about herbicide resistance, access to chemicals, and environmental impacts highlight the need for alternative weed control strategies accessible for smallholders. Farmers in semi-arid regions contend with the additional challenge of low biomass production, which may limit the weedsuppressing benefits of permanent soil cover. This paper reviews the regional applicability of various mechanical (manual weeding, weeding using animal traction, weed seed harvest), thermal (soil solarization, weed steaming, flaming), chemical (herbicides, seed coating), and cultural (crop competition, crop residue retention, intercropping, crop rotation) weed control strategies. For each strategy, benefits and challenges were assessed and contextualized with the circum-
\end{abstract}

Nicole Lee

Nicole.Lee@uni-hohenheim.de

1 Hohenheim Tropics, Universität Hohenheim, Garbenstrasse 13, 70599 Stuttgart, Germany

2 Universitätsstrasse 1, 70569 Stuttgart, Germany

3 CIMMYT, Southern African Regional Office, Mount Pleasant, P.O. Box MP 163, Harare, Zimbabwe stances of rainfed smallholder farmers in southern Africa. We found that (1) no single solution can solve all weed control challenges under current conservation agriculture systems; (2) success of weed control strategies is largely contingent upon site-specific conditions, including soil type, dominant weed species, and socioeconomic factors; and (3) practices new to southern Africa, such as weed steaming, merit localized research. Previous reviews have addressed various weed control strategies, but a comprehensive review of strategies available to smallholder farmers in semi-arid southern Africa is lacking. Finding a suitable combination of weed control strategies is critical for encouraging smallholder farmers to adopt and maintain conservation agriculture practices.

Keywords Mechanical weed control $\cdot$ Chemical weed control $\cdot$ Herbicides $\cdot$ Cultural weed control $\cdot$ Semi-arid agriculture $\cdot$ No-tillage

\section{Contents}

1. Introduction

2. Methodology

3. Overview of weed management under conservation agriculture

4. Weed management in rainfed dryland areas of southern Africa

5. Weed management strategies

5.1. Manual and mechanical control

5.1.1. Manual weeding

5.1.2. Animal traction mechanical control

5.2. Thermal control

5.2.1. Soil solarization

5.2.2. Weed flaming

5.2.3. Weed steaming 
5.3. Chemical control

5.3.1. Herbicides

5.3.2. Seed coating

5.4. Cultural control

5.4.1. Enhanced crop competition using planting and fertilization calendars

5.4.2. Crop residue retention

5.4.3. Intercropping

5.4.4. Crop rotation

5.4.5. Harvest weed seed control

6. Summary of weed control strategies

7. Conclusion

Acknowledgements

References

\section{Introduction}

Soil degradation affects farmers worldwide, including those in semi-arid regions of southern Africa (Tittonell et al. 2012). Conservation agriculture (CA) has been proposed as an alternative to conventional tillage practices over the last four decades and has been increasingly tailored to Asia and Africa (see recent reviews from Jat et al. 2013; Wall et al. 2014). Since 2004, there has been a major push by researchers, non-governmental, and donor organizations to extend CA to smallholder farming systems in southern Africa (Sims et al. 2012b; Thierfelder et al. 2014; Wall et al. 2014). Soils in southern Africa are affected by parent soil material of granitic origin, which is low in fertility (Smaling and Janssen 1997), low use of chemical and organic inputs (Mafongoya et al. 2006), and unsustainable land use practices (Wall et al. 2014). Soil degradation from conventional tillage practices emphasizes the importance of systems that increase soil organic matter content and improve soil structure (Johansen et al. 2012; Tittonell et al. 2012). The vulnerability of smallholder rainfed farming systems to erratic and reduced rainfall associated with climate change further highlights the need for farming practices that adapt to the impacts of climate change (Thierfelder and Wall 2010a, b; Thierfelder et al. 2017).

CA comprises a set of three principles, as outlined by the FAO (2002): minimal mechanical soil disturbance, permanent organic soil cover, and diversification of species through the use crop rotation and intercropping. Rather than presenting a strict set of rules, CA provides guidelines for growing crops in a more sustainable way, which can be tailored to fit local contexts and needs. These guidelines allow farmers to adapt CA practices to regional conditions, such as soil type, rainfall patterns, and financial resources (Wall 2007). Regardless of how a farmer adopts CA, the prospective benefits remain: decreased soil erosion, increased soil water holding capacity, improved soil structure, increased soil fertility over time, a gradual increase in soil carbon, and similar or increased yields as compared to conventional tillage systems (Walsh et al. 2013; Thierfelder et al. 2015; Brady and Weil 2010; Thierfelder et al. 2014).

Some benefits of CA implementation, such as soil water content and infiltration, are evident within the first year of CA implementation (Thierfelder and Wall 2009; Thierfelder and Wall 2010a, b). However, other gains from CA take much longer to establish themselves (Rusinamhodzi et al. 2011). Soil fertility improvement under CA systems can be quite slow due to the length of time required to sufficiently increase soil organic matter content (Cheesman et al. 2016; Govaerts et al. 2009). According to Arslan et al. (2014), farmers in Zambia did not recognize the soil health benefits of CA practices during the first 4 years of adoption, while a study in Mexico found that yield benefits were negligible during the first 5 years (Hobbs et al. 2008). A study from southern Africa concluded that it takes between 2 and 5 years for yield benefits to become apparent, in part due to farmers becoming more experienced with applying CA practices (Thierfelder et al. 2015). Other benefits such as improved profitability, labor reductions,and increased water conservation can additionally incentivize farmers to adopt CA in the short term and continue practicing it (Baudron et al. 2015b; Thierfelder et al. 2016a, b).

One of the greatest challenges associated with CA implementation in the early years of conversion is the increase in weed pressure as a result of eliminating tillage as a weed control mechanism (Chauhan et al. 2012; Giller et al. 2009). Consequently, finding appropriate weed management strategies is crucial for maintaining adequate yields (see Fig. 1) and compensating for additional labor demands in the first years after CA implementation, thereby ensuring continued use of CA practices thereafter (Mavunganidze et al. 2014; Muoni et al. 2013).

Time and labor demands can increase by up to $50 \%$ under $\mathrm{CA}$ as a result of increased weed pressure (Nyamangara et al. 2013), which highlights the critical need for improved weed

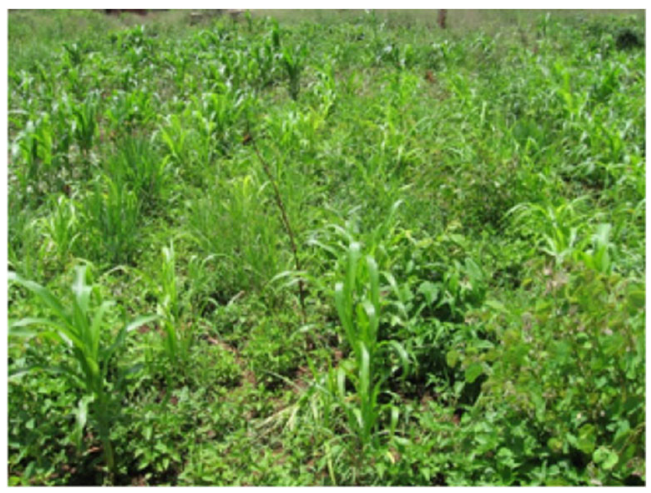

Fig. 1 A typical smallholder maize field with delayed weeding in Bindura District, Zimbabwe. Delayed weeding is associated with high yield losses in many parts of southern Africa. Finding effective weed management practices with low labor demands is therefore a crucial element to enhancing food security for smallholder farmers practicing conservation agriculture. Source: Christian Thierfelder, CIMMYT 
control strategies if CA should be an option for smallholder farmers in southern Africa. A study in Zambia found that labor demands increased from 27 person days per ha under conventional tillage to 35,58 , and 81 person days per ha under ripper tillage, hand hoe tillage, and planting basins, respectively (Haggblade and Tembo 2003). Traditional weed control is done by hand pulling of weeds, by using a hand hoe (locally called badza), which can have a short or long handle, and through more mechanical systems such as animal traction cultivators.

Other studies indicate that increased weed pressure in CA systems often results from farmers failing to adhere strictly to no-tillage practices. In fact, tilling the soil, even once, may reduce the benefits of CA (Anderson 2015). A study in southern Brazil found that soil disturbance from seeding machines may be sufficient to expose weed seeds to the environmental conditions (e.g., light and moisture) necessary for germination, whereas an undisturbed soil surface, in conjunction with crop residue retention, may be sufficient to inhibit weed seed germination (Theisen and Bastiaans 2015). The same study found that weed pressure was greater within soybean rows where the soil had been disturbed during seeding than in rows seeded using a modified seeder that left crop residue intact and did not disturb the soil (Ibid.). Although the study by Theisen and Bastiaans (2015) addressed soil disturbance during seeding, it is reasonable to assume that soil disturbance during the weeding process may have similar impacts on the weed seed bank. This implies that strictly following no-tillage guidelines may reduce weed pressure for farmers who have recently converted to CA practices.

Approximately $75 \%$ of smallholder farms in sub-Saharan Africa use hoe-weeding or hand pulling as a weed management strategy; finding supplementary methods to hoeweeding is therefore essential for easing labor demands in CA systems. Herbicide use, for example, is estimated to reduce labor demands for weeding by $90 \%$ as compared to hoeweeding (Gianessi et al. 2009). A study in Zambia reported that herbicide use had the potential to reduce labor demands from 50-70 to 10-20 person days per ha (Haggblade and Tembo 2003). Labor reductions provide an additional social benefit as manual weeding in southern Africa is frequently taken on by women and children, and any reduction is beneficial for these household members (Ibid.).

Much of the research previously conducted on weed suppression under CA systems focused on large-scale commercial farms in Australia and the Americas or on humid areas of the tropics and subtropics (Flower et al. 2012; Moyer et al. 1994; Odhiambo et al. 2015). While several researchers have focused on weed ecology and control under smallholder CA systems in semi-arid areas Africa (Mashingaidze et al. 2012; Mhlanga et al. 2015b; Muoni and Mhlanga 2014; Muoni et al. 2014; Nyamangara et al. 2013; Thierfelder and Wall 2015, among others), a comprehensive review and summary of the options available and alternatives to smallholder farmers in southern Africa has been missing.

The overall objective of this literature review was therefore to fill this knowledge gap by compiling available research results of weed management studies under dryland CA systems and applying them to the context of southern Africa.

\section{Methodology}

The review examines the literature on weed control strategies available to smallholder farmers to address the issue of weed management under CA and provides insight as to how the application of these strategies and approaches might be tailored to the context of dryland farming areas of southern Africa. Literature searches were conducted using popular search engines such as Google Scholar (https://scholar. google.com/), Scopus (http://www.scopus.com), and Web of Science (www.webofknowledge.com). Search criteria focused on literature addressing weed control under smallholder CA systems in southern Africa which was reviewed to ascertain the most relevant findings on this topic (Table 1).

The following Sect. 3 provides a general overview of weed management strategies under CA systems throughout the world. Section 4 highlights the importance of weed species and their impact on crop yields in southern Africa, as well as the field and resource characteristics of smallholder farms in the region. Section 5 focuses on potential weed management strategies appropriate for smallholder farmers in semi-arid regions of southern Africa, while highlighting their benefits and constraints. The sixth section provides a summary of available weed control strategies as well as recommendations for researchers and extension workers for managing weed populations under CA systems. The review ends with concluding

Table 1 Search criteria for the literature review conducted on weed control in rainfed conservation agriculture systems of southern Africa

conservation agriculture AND weed control OR weed management OR weeds AND semi-arid AND Zimbabwe OR Zambia OR Malawi OR Lesotho OR South Africa OR Southern Africa OR Mozambique OR Botswana OR Namibia

conservation agriculture AND weed control OR weed management or weeds AND semi-arid AND sub-Saharan Africa

conservation agriculture AND weed control OR weed management OR weeds AND semi-arid tropics OR semi-arid subtropics

conservation agriculture AND weed control OR weed management OR weeds

When region-specific information was lacking, the search criteria were broadened to include other elements. The literature search was conducted using Google Scholar, Scopus, and Web of Science. Source: author's own compilation 
statements and the outlook of weed management under CA for smallholder farmers.

\section{Overview of weed management under conservation agriculture}

Conflicting findings regarding the impact of conventional tillage on weed population dynamics contribute to variable results of how weed pressure is affected by CA practices. Several studies report that conventional tillage contributes to weed control through burying of weeds and weed seeds into lower soil layers, thereby limiting their exposure to favorable germination conditions (Nakamoto et al. 2006). Other studies have found that tillage can have both a negative and positive effect on weed seed banks: tillage may temporarily incorporate some weed seeds into deeper layers while bringing others to the soil surface where they are exposed to the conditions necessary for germination (Carter and Ivany 2006; SantínMontanyá et al. 2016). A study on wild oat (Avena fatua L.) in Alberta, Canada determined that tillage practices resulted in higher weed pressure for two reasons: first, tillage buried wild oat seeds deeper within the soil profile, thereby limiting their exposure to herbicides (Mangin et al. 2016). Secondly, the relatively large seed size of wild oat allows it to germinate from greater depths within the soil, thus negating the benefits of burying the seeds through tillage (Ibid.). Similarly, a study in Iran found that purple nutsedge (Cyperus rotundus L.) tubers are able to germinate from soil depths as great as 30 $50 \mathrm{~cm}$, thereby defeating the purpose of tillage to control weeds (Roozkhosh et al. 2017). The role of tillage in suppressing weed populations therefore seems to be contingent on multiple factors, including weed species and tillage type. As summarized by Chauhan et al. (2006), weed species with germination requirements that are met by remaining within the top five centimeters of the soil (such as small-seeded weeds that require light to break dormancy) will more likely become the dominant species within no-tillage and minimum tillage systems. Weed species within an area therefore must be understood in order to determine how conversion to CA will affect weed population dynamics.

Weed management under CA may be more difficult for two reasons: (1) weed seeds are not buried and (2) herbicides are not incorporated into the soil, lowering their efficacy (Chauhan et al. 2012). As compared to conventional tillage practices, no-tillage and minimum tillage systems restrict redistribution of weed seeds to the top zero to five centimeters of soil (Swanton et al. 2000). While the likelihood of seed desiccation and predation is greater at the soil surface than at greater soil depths, weed seeds within the top five centimeters of soil are also exposed to more favorable germination conditions (Chauhan et al. 2012). As a result, weed density is typically higher when the soil is not inverted than under conventional tillage systems, especially in the first years of conversion (Demjanová et al. 2009). However, with good weed management, weed pressure should decrease over time, often within the first few years of CA adoption (Thierfelder and Wall 2015; Wall et al. 2014; Muoni et al. 2014). Nevertheless, conflicting results have been published regarding the prevalence, distribution, and diversity of weed populations under CA systems compared to conventional tillage systems: a study by Chauhan et al. (2012) found that some weed species (predominantly annuals) are better-managed in CA systems due to seed desiccation and predation by insects when left at the soil surface, while another study indicated that intensive weed management is necessary even 4 years into CA conversion (Mashingaidze et al. 2012).

Similarly to many conventional tillage farming systems, large-scale commercial CA systems in Brazil, Argentina, Australia, Canada, and the USA control weed populations through a combination of several herbicides and rotations of three or four crop species (Moyer et al. 1994). In these systems, several applications of non-selective herbicides, such as glyphosate [ $N$-(phosphonomethyl) glycine] and paraquat (1,10-dimethyl-4,40-bipyridinium) in conjunction with residual herbicides such as atrazine (2-chloro-4-ethylamino-6isopropylamino-1,3,5-triazine) or a combination of residual herbicides like topramezone \{[3-(4,5-dihydro-3-isoxazolyl)2-methyl-4-(methylsulfonyl)phenyl](5-hydroxy-1-methyl1H-pyrazol-4-yl)methanone 3 and dicamba (3,6-dichloro-2methoxybenzoic acid), such as Stella Star®, during fallow periods and in-between crops are considered crucial for successful weed control (Ibid.). Similar application practices are common in southern Australia: during the fallow period, before the field is seeded, farmers apply non-selective herbicides. Soil residual herbicides are then applied during seeding, followed by post-emergent herbicides during the cropping season (Neve et al. 2003; Owen et al. 2014). Weed populations may additionally be controlled by maintaining nearpermanent soil cover and 3- or 4-year crop rotations.

The worldwide increase in area under no-tillage agriculture, which was later coined as CA, was largely attributed to a decrease in herbicide prices (Llewellyn et al. 2012; Kassam et al. 2015), highlighting a strong driver of change. A 2006 duration analysis indicated that a decrease in the glyphosate/diesel price ratio in Australia resulted in a significant increase in adoption of no-tillage practices (D'Emden et al. 2006). While other factors influence farmer adoption of CA practices, facilitating uptake of specific principles, such as minimum or no soil disturbance, is an important starting point in the use of CA. Thus, CA adoption in southern Africa may be dependent on affordability of herbicides for smallholder farmers.

Other driving factors for adoption of CA in Australia may be similarly relevant for farmers in southern Africa. Many Australian farmers were found to be motivated by a reduction 
in soil erosion and a desire to improve stewardship of the soil (Llewellyn et al. 2012). Farmers were additionally encouraged by the potential to increase soil moisture under CA systems and take advantage of earlier planting times (Ibid.) Extension and support services for farmers adopting CA are also key to motivating farmers to both take up CA practices and continue implementing them (D'Emden et al. 2008; Llewellyn et al. 2012). These factors should be taken into consideration when encouraging farmers to adopt CA.

The adverse environmental effects of accelerated herbicide use are well documented (Koch 2010; Kolpin et al. 1998; Owen and Zelaya 2005). While herbicide use has succeeded in suppressing weed populations of farms under CA, use of herbicides as a sole control mechanism increases the risk of herbicide-resistant weeds (Norsworthy et al. 2012). In many CA systems in Australia, farmers turned almost exclusively to herbicide use to address increases in weed populations due to no-tillage practices, leading to massive weed resistances against potent herbicides such as glyphosate (Kirkegaard et al. 2014).

Herbicide leaching is an often-cited externality of herbicide use. Herbicides may persist in the soil, volatilize, or go into soil solution and be transported to nearby bodies of water; atrazine has reportedly been found in numerous water reservoirs throughout the USA (Arias-Estévez et al. 2008). In Zambia, increased use of herbicides by commercial farmers resulted in contamination of the Kafue River and herbicide bioaccumulation in the river's fish populations (Syakalima et al. 2006). While this indicates that over-reliance on and/or improper use of herbicides may negate the potential benefits of adopting CA practices and cause undesired impacts on the environment, it should also be noted that tillage practices play a significant role in herbicide transfer in the soil-water solution.

Conflicting results regarding the impact of tillage on herbicide runoff highlight the importance of understanding transport mechanisms of different herbicides before recommending their use to farmers. One study in the USA compared atrazine [2chloro-4-(ethylamino)-6-(isopropylamino)-s-triazine] and simazine [2-chloro-4,6-bis(ethylamino)-s-triazine] runoff rates under conventional tillage and no-tillage systems and found that runoff for both herbicides was higher under conventional tillage (Glenn and Angle 1987). Conversely, another study in the USA found that although runoff and soil loss decreased under conservation tillage (including no-tillage) systems, atrazine, alachlor [2-chloro-2'6'-diethyl- $N$-(methoxymethyl) acetanilide), and chlorpyrifos [0,0-diethyl-0-(3,5,6-trichloro-2-pyridyl) phosphorothioate) concentrations were higher under conservation tillage than under conventional tillage practices (Sauer and Daniel 1987). A more recent study on alachlor and chlorimuron \{ethyl 2-[(4-chloro-6-methoxypyrimidin-2yl)carbamoylsulfamoyl]benzoate $\}$ reported that alachlor loss was greater from bare, tilled plots, while chlorimuron loss was greater on no-tillage plots with residue cover (Locke et al. 2008). The authors attributed the difference to the polarity of the herbicide molecules: polar chlorimuron may have been more readily removed from the surface of plant residues than alachlor, which has weaker polarity (Ibid.). It should be noted, however, that the studies by Sauer and Daniel (1987) and Locke et al. (2008) were conducted under simulated rainfall conditions; thus, the results from a field with natural rainfall may be quite different and require further study to better understand the mechanisms of herbicide transport in no-tillage and reduced tillage systems. Therefore, herbicide application, even on fields with minimal soil disturbance, must be done cautiously and by a trained applicator.

In order to limit over-reliance on herbicides for weed control under CA systems for cash-constrained smallholder farmers, numerous alternative methods have been proposed, including manual and hoe weeding (Mandumbu et al. 2011), low-powered mechanical control (Siziba 2007), seed coating (Kanampiu et al. 2003), crop competition (Mhlanga et al. 2016a, b), soil solarization (Johnson et al. 2007), weed flaming (Stepanovic et al. 2015), weed steaming (Ascard et al. 2007), suppression through crop residue retention (Mazvimavi and Twomlow 2009), green manure cover crops (Mhlanga et al. 2015a, 2016b) intercropping (Iqbal et al. 2007), crop rotations (Chauhan et al. 2012; Norsworthy et al. 2012), and harvest weed seed control (Stokstad 2013). This paper will examine the feasibility of these solutions within the context of smallholder farming systems in semi-arid zones of southern Africa.

\section{Weed management in rainfed dryland areas of southern Africa}

Several studies on weed management under CA promote the use of herbicides as a solution for alleviating weed pressure, particularly in the early phases of CA implementation (Chauhan et al. 2012; Muoni et al. 2014). However, increased herbicide application alone may be an unrealistic weed management tool in southern Africa, particularly for resource-poor and cash-constrained smallholder farmers. Therefore, a combination of chemical, mechanical, and cultural control practices should be explored to ensure continued weed control in CA systems for the farmers who are most vulnerable to weed pressure.

Despite the success of some CA systems in the Americas, herbicides are restricted in their applicability to the context of southern Africa for several reasons. Herbicide prices and availability are a limiting factor for their use among smallholder farmers in southern Africa. In addition, appropriate herbicide application requires knowledge and training; this necessitates effective extension services to provide information to farmers (Thierfelder et al. 2016b). Near-permanent or 
permanent soil cover may be feasible under irrigated or rainfed systems with sufficient moisture, but maintaining crops on the field throughout the year is unrealistic in rainfed agricultural systems with annual precipitation rates below $600 \mathrm{~mm}$. Here unpredictable and insufficient rainfall often leads to low biomass productivity (Lahmar et al. 2012). This challenge is especially prevalent in areas with unimodal rainfall patterns, common to most areas in southern Africa (Challinor et al. 2007; Rusinamhodzi et al. 2011; Thierfelder and Wall 2010a). Two additional obstacles to maintaining soil cover are cited in the literature: competition with livestock for biomass as fodder (Valbuena et al. 2012) and limited incentives for farmers to plant crop species other than maize due to low market demand for rotational crops and few buyers for their produce (Nyamangara et al. 2013).

Among the most economically important broadleaf weed species in southern Africa are bristly starbur (Acanthospermum hispidum DC.), wandering Jew (Commelina benghalensis L.), Mexican clover (Richardia scabra L.), yellow nutsedge (Cyperus esculentus L.), purple nutsedge (C. rotundus L.), and witchweed (Striga asiatica L.) (Chivinge 1988; Mupangwa and Thierfelder 2015). Rapoko grass (Eleusine indica L.) and couch grass (Cynodon dactylon $\mathrm{L}$.) are listed as economically important grass species (Mupangwa and Thierfelder 2015). The impacts of these weed species on farmer labor demands and yields are quite high: several authors found that a lack of labor and mechanization to facilitate weeding lead to a decrease in cultivated land area under CA of nearly 50\% in sub-Saharan Africa (Kent et al. 2001; Bishop-Sambrook 2003, as cited in Nyamangara et al. 2013). Striga (S. asiatica (L.) Kuntze) infestation alone has led to severe reductions in yield (greater than 50\%, in some cases) throughout sub-Saharan Africa (Kanampiu et al. 2003).

Successful weed management in smallholder farming systems in southern Africa is largely determined by three factors: labor availability, access to herbicides, and access to mechanization (Mhlanga et al. 2016b; Nyamangara et al. 2013). Access to resources varies widely across smallholder farms throughout Africa (Ngwira 2013; Tittonell et al. 2005); as a result, a control method that is effective in one area may fail in another. Proposed strategies for weed management should therefore take different site and farmer conditions into account (Wall 2007).

\section{Weed management strategies}

\subsection{Manual and mechanical control}

Manual and mechanical weed controls (often with the use of animal traction) are the most common weed management strategies for smallholder farmers in sub-Saharan Africa (Gianessi et al. 2009). This section focuses on two methods of mechanical control: manual weeding and weeding using animal traction and addresses factors affecting their efficacy.

\subsubsection{Manual weeding}

Mechanical weed control via hand pulling or hand hoeing is a frequent management tool for smallholder farmers in southern Africa (Mashingaidze et al. 2012; Vogel 1994). In CA systems, labor demands for mechanical weed control may increase due to greater weed pressure during the initial years of CA adoption (Mashingaidze et al. 2012; Muoni et al. 2013; Nyamangara et al. 2013). These labor demands often differ greatly based on the weed management strategy used (see Table 2). In order to comply with the principles of CA, farmers using hand hoes for weed control must use the tool for shallowly scraping the soil surface to remove weeds, rather than employing a digging motion, which may be more time consuming. Insufficient labor availability to suppress weed populations is thus a major challenge for smallholder farmers adopting CA technologies (Giller et al. 2009). Delayed weeding can have drastic impacts on crop productivity as weeds compete for light, nutrients, and water with the main crop.

Farmers with adequate labor supply may enhance the benefits of manual or mechanical weed control by timely weeding of fields (Vogel 1994). High-intensity weeding, conducted four times throughout the growing season (1 week before planting, 1 week after planting, 5 weeks after planting, and before harvest) resulted in similar early season weed densities between minimal tillage and moldboard-plow tillage systems in a semi-arid region of Zimbabwe (Mashingaidze et al. 2012). However, high-intensity weeding is challenging to labor- and resource-constrained famers. Women and children also bear the brunt of increased labor demands for weeding (Giller et al. 2009). In addition, in some cases, higher weed densities are found even under high-intensity weeding practices in CA systems as compared to conventional tillage systems (Mashingaidze et al. 2012), thereby highlighting the need for alternative weed control strategies.

\subsubsection{Animal traction mechanical control}

Suitable mechanical cultivators for weed control are an alternative to conventional tillage and are often used where draft animals are available (Riches et al. 1997). Cultivators can help reduce weed pressure, although they may not be as effective as conventional tillage methods for preparing weed-free planting beds (see Table 3). Smallholder farmers may benefit from animal-drawn cultivators such as soil rippers, which are tools mounted on a frame with multiple tines. These can be an effective form of mechanical weed control (see Fig. 2) through mechanical disturbance of small and emerging weeds (Mafongoya et al. 2016; Twomlow and O'Neill 2003). A drawback of mechanical cultivators is their inefficiency and 
Table 2 Comparison of labor use based on six different weeding practices: basin digging, hand hoeing, soil ripping, plowing, oxen-drawn plowing, and herbicides

\begin{tabular}{|c|c|c|c|c|c|c|}
\hline \multirow[t]{2}{*}{ Labor use } & \multicolumn{6}{|c|}{ Weeding practice } \\
\hline & Basin digging & Hand hoeing & Ripping & Plowing & Oxen & Herbicides \\
\hline Number of person days/ha & $20.2 \mathrm{a}$ & $23.8 \mathrm{a}$ & $22.0 \mathrm{a}$ & $16.9 \mathrm{a}$ & $12.8 \mathrm{~b}$ & $18.2 \mathrm{a}$ \\
\hline Normal season weeding times & $2.2 \mathrm{a}(0.6)$ & $2.2 \mathrm{a}(0.7)$ & $2.4 \mathrm{a}(0.6)$ & $1.9 \mathrm{a}(0.3)$ & $4.4 \mathrm{~b}(0.3)$ & $3.8 \mathrm{c}(1.4)$ \\
\hline Total no. of workers weeding/ha & $28.5 \mathrm{a}(22.4)$ & 29.5a (17.1) & $26.2 \mathrm{a}(39.2)$ & $19.5 \mathrm{a}(17.1)$ & $4.3 b(2.0)$ & $13.9 \mathrm{c}(16.3)$ \\
\hline$N$ & 68 & 10 & 55 & 112 & 54 & 28 \\
\hline
\end{tabular}

Different letters indicate significance at $p \leq 0.05$. Impacts of different weeding practices on number of person days per hectare, weeding times, and total number of workers weeding per hectare were evaluated. Source: Adapted from Umar et al. (2012), p. 919.

impracticality when large quantities of plant residues are present (Erenstein 2003). They are therefore only suitable where residue cover is low (Mazvimavi et al. 2010) which is often the case in the more semi-arid regions of southern Africa.

Extension agencies, service providers, or cooperatives could supply smallholder farmers with access to mechanized cultivators. This approach would eliminate the need for largescale investments, which smallholder farmers would be unable to make. It would also reduce the waiting time for farmers in a community to access weeding equipment (Najafi and Torabi Dastgerduei 2015). Weed populations are largely affected by crop planting time; as such, timely seedbed preparation is essential for reducing crop-weed competition (Mhlanga et al. 2016a). As the land holdings of many smallholder farmers in southern Africa are far smaller than five hectares, localized joint ownership or service provision of low-powered or draught-powered machinery that disturbs the soil as little as possible may be the most realistic method of providing farmers access to mechanized planting and weed control technologies (Baudron et al. 2015a).

Table 3 Comparison of three types of tillage and their effects on weed density (number of plants $\mathrm{m}^{-2}$ )

\begin{tabular}{lllll}
\hline & \multicolumn{3}{l}{ Tillage } & \\
\cline { 2 - 5 } Weed groups & CT & RT1 & RT2 & Average \\
\hline Annual grassy & 4.8 & 11.0 & 14.3 & $10.0 \mathrm{~b}$ \\
Broadleaves & 8.9 & 19.2 & 14.9 & $14.3 \mathrm{c}$ \\
Perennials & 2.6 & 9.0 & 7.5 & $6.4 \mathrm{a}$ \\
Total weed density & $16.3 \mathrm{a}$ & $39.2 \mathrm{~b}$ & $36.7 \mathrm{~b}$ & \\
\hline
\end{tabular}

Different letters indicate significant difference at a $p \leq 0.05$ level. Both reduced tillage practices resulted in higher weed densities than the CT treatment, although RT2 had slightly lower weed densities (not significant) than RT1. Source: Adapted from Demjanová et al. (2009), p. 788

$C T$ conventional tillage (moldboard plowing to a depth of $0.3 \mathrm{~m}$ ), RT1 reduced tillage offset disc plowing (depth of $0.15 \mathrm{~m}$ ) and combined cultivator, $R T 2$ reduced tillage shallow loosening of soil twice prior to planting (depth of $0.1 \mathrm{~m}$ ).
Government and NGO-driven initiatives could further improve access to small-scale machinery by encouraging local production. FAO field projects in Tanzania and Kenya have sought to establish market linkages and the local manufacturing sector of other CA tools, such as the hand jab planter (Sims et al. 2012a). Zimbabwe has already begun private sector manufacturing of important CA tools, including no till (NT) planters and draft animal powered (DAP) rippers, while Zambia has also developed its local production sector aimed at manufacturing rippers for smallholder farmers (Sims et al. 2012b). Similar initiatives could therefore be supported in other countries of southern Africa.

In summary, both manual weeding, hoe weeding, and weeding via animal traction are commonly used methods of

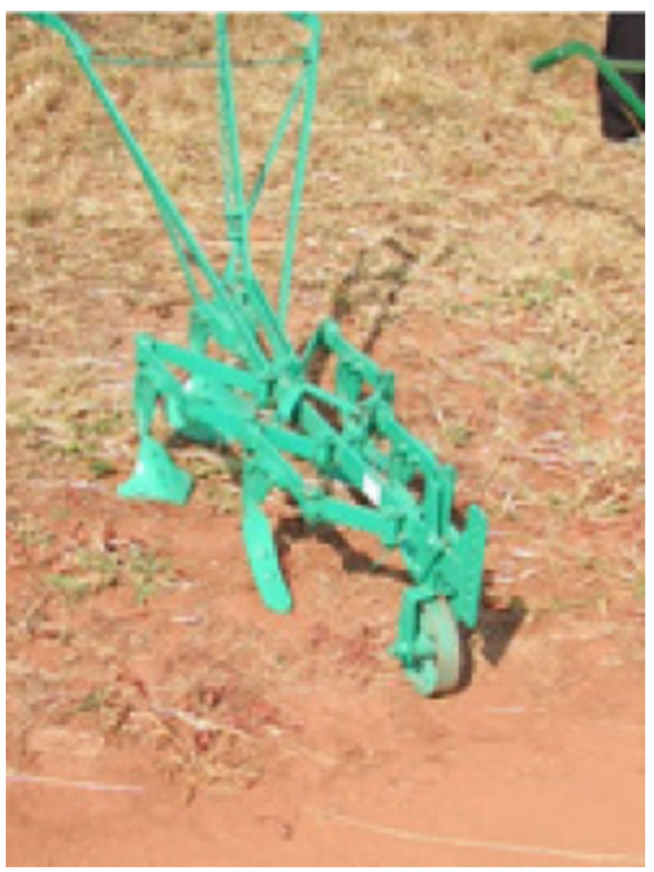

Fig. 2 The animal drawn cultivator is commonly used by smallholder farmers with access to animal draft power. These cultivators superficially disturb the soil, while still providing some of the weed suppressing benefits associated with tillage practices. Such cultivators can provide labor relief to smallholder farmers. Photo credit: Joseph Kienzle, FAO 
weed control in southern Africa. While they can successfully control weed populations under CA systems, these techniques can be enhanced by proper timing of weeding, thereby reducing labor demands (see Fig. 3).

\subsection{Thermal control}

Soil solarization and weed flaming are rarely used in southern Africa but present an unexplored option for smallholder farmers. Their applicability to smallholder farmers in the region is discussed in this section to seek alternatives to the currently existing methods of weed control.

\subsubsection{Soil solarization}

In areas where crop competition or low biomass production limit the quantity of residues that can be maintained on the field, alternative solutions for suppressing weeds via soil

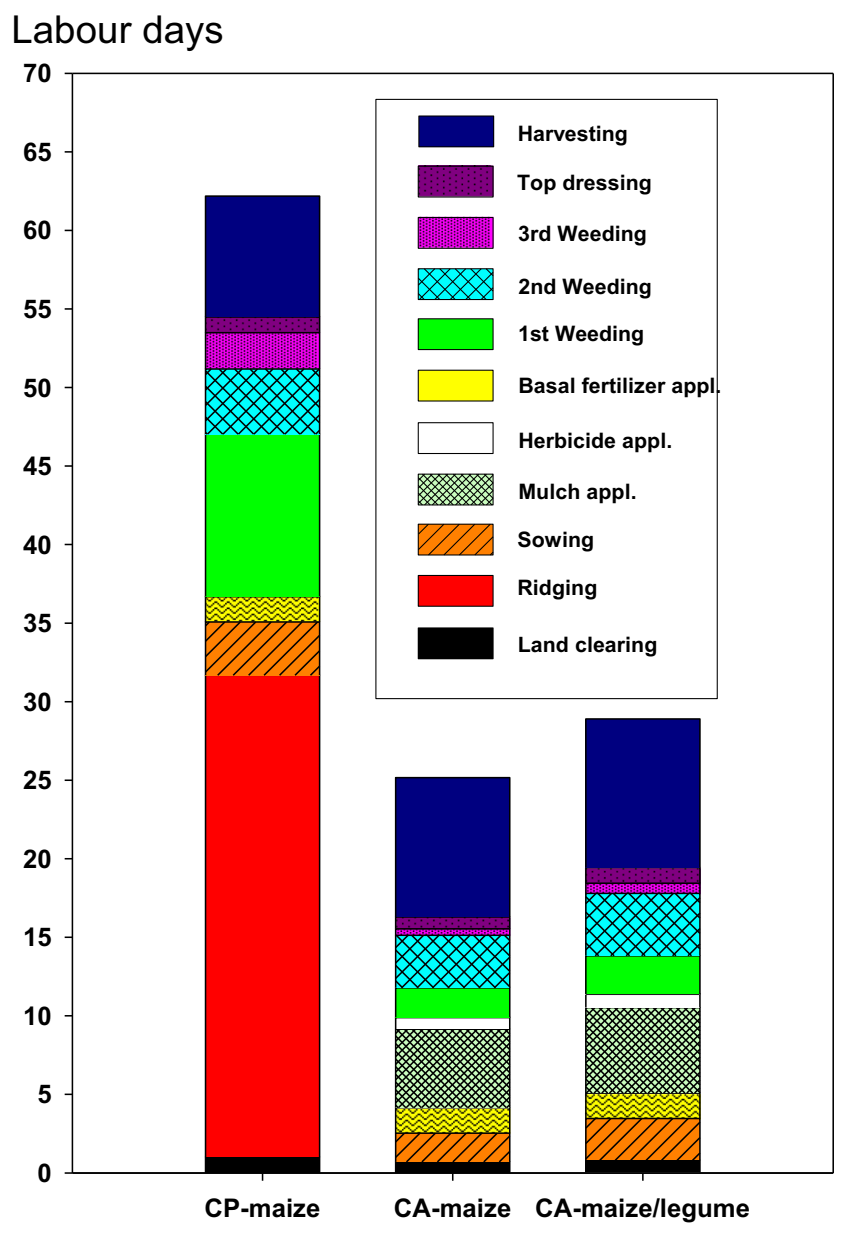

Fig. 3 Labor distribution in general farmer operations from land clearing to harvest. Weeding was done with herbicides on CA fields. CP-maize $=$ conventional practice with maize; $\mathrm{CA}$-maize = conservation agriculture with maize; CA-maize/legume $=$ conservation agriculture with maize cowpea intercropping, Mwansambo, Malawi. Adapted from Thierfelder et al. (2016a, b), p. 592 cover may be necessary (Erenstein 2003; Valbuena et al. 2012). Soil solarization, a process by which transparent or black plastic sheets are used as mulch to increase soil temperatures to levels lethal to bacteria, fungi, and weeds and weed seeds (Stapleton and DeVay 1986), is a potential option for smallholder farmers faced with the challenge of residue retention. Soil solarization has been successfully used to control weed species in semi-arid regions with minimal cloud cover (Johnson et al. 2007). Soil solarization can suppress kudzu (Pueraria montana var. Lobata Willd) in the southeastern USA and eradicated weedy golden wreath wattle seedbacks (Acacia saligna Labill.) in Australia (Norsworthy et al. 2012). A study of soil solarization effects on Orobanche ramosa L. and Orobanche cernua L. in tomato fields in the Central Rift Valley of Ethiopia found that both black and transparent plastic sheets reduced the Orobanche seed bank by up to 89 and $98 \%$, respectively (Sahile et al. 2005).

Although soil solarization as a weed control method may not be common in CA, one of the lessons learned has been that it needs to be tried and potentially adapted to local conditions. In the case of smallholder farmers in semi-arid southern Africa, adequate mulch retention for weed suppression may not be an option for smallholders due to low biomass production and tradeoffs with livestock (Valbuena et al. 2012). Soil solarization may therefore be an option for farmers who are unable to retain enough mulch on the soil to reap its benefits. However, plastic sheeting as surface mulch comes with an extra cost and cash-constrained households will have to consider if this is viable for them.

Effective soil solarization is largely contingent upon proper timing and temperature (Ascard et al. 2007). Temperatures ranging from 55 to $95{ }^{\circ} \mathrm{C}$ are needed to effectively kill weed leaves and stems, with higher temperatures resulting in greater weed mortality (Daniell et al. 1969). A study on control of yellow nutsedge using clear plastic sheets effectively controlled weed pressure when the soil was solarized for at least 90 days during the summer of the previous year (Johnson et al. 2007). While these results are certainly encouraging, farmers would have to leave fields fallow to reap the benefits of soil solarization (Ibid.). In many areas of southern Africa, the opportunity costs of leaving land fallow are high, making this option less appropriate for those farmers (Mafongoya et al. 2006). This practice is also less effective if weed seeds are not distributed in the top layers of the soil surface, as the benefits of the increased soil temperatures are reduced in lower soil layers (Johnson et al. 2007). Furthermore, the weed-suppressing effects of soil solarization are greatly affected by environmental factors over which farmers may have little or no control, such as soil moisture, cloud cover, low temperatures, and soil color (Stapleton 2000; Stapleton and DeVay 1986).

While soil solarization may be an effective weed management practice for some farmers, several challenges highlight the need for more research. There is a lack of consensus on the 
efficacy of soil solarization for weed management (Johnson et al. 2007) as well as additional costs incurred by responsible disposal of the plastic sheets (Coello et al. 2017) which make soil solarization a less attractive option for weed management. Nonetheless, the potential of biodegradable materials for soil solarization has been identified (Ibid.) and may be an interesting new way of controlling weeds. Until more thorough studies have been conducted regarding local applicability and adequate materials have been developed, this method of weed control remains out of reach for most smallholders in southern Africa.

\subsubsection{Weed flaming}

Weed flaming is another weed control strategy, successfully tried outside Africa. Although it has often been used for horticultural crops, it has been used effectively for maize production in Europe and the USA (Melander et al. 2013; Stepanovic et al. 2015). Flaming exposes weeds to lethal temperatures to provide rapid weed control without the use of chemical inputs (Ascard et al. 2007). In weed flaming, handheld or machine-pulled portable gas (generally propane) torches are used to expose weed seeds and seedlings to lethally high temperatures before sowing (Stepanovic et al. 2015). Weed flaming can be used in two ways: (i) with stale seedbeds, whereby fields are prepared several weeks prior to sowing in order to encourage weed growth and kill emerging weeds before sowing (Rasmussen 2003) or (ii) during the growing season as an intra-row spot weed control mechanism (Stepanovic et al. 2015).

As with soil solarization, the success of weed flaming depends on both timing and temperature (Ascard et al. 2007). A study on weed flaming as a weed control mechanism in organic maize production systems found that broadcast flame weeding twice a season resulted in decreased weed density with limited crop damage (Stepanovic et al. 2015). A study in Denmark found that weed density in fodder beet (Beta vulgaris L.) fields was lowest when weed flaming was used in conjunction with stale seedbed production combined with punch planting, a form of minimal tillage (Rasmussen 2003).

No research has been conducted so far on weed flaming in sub-Saharan Africa, so it is difficult to predict how successfully this technology might be applied to smallholder farming systems in semi-arid regions of southern Africa. Several factors need to be considered when recommending weed flaming technologies to smallholder farmers. Weed flaming is not suitable for all crop species, so farmers must first be educated on which crops are sufficiently heat-tolerant and at which stage weed flaming is appropriate (Naylor and Lutman 2002). Secondly, crop residue retention, particularly in semi-arid regions, could hinder the efficacy of weed flaming and increase the risk of fires; it is thus essential that farmers be trained in correct usage of this technology. In addition, not all weed flamers are built the same. Covered weed flamers have been found to use $40 \%$ less fuel than uncovered flamers to effectively control weeds (Ascard 1995). Smallholder farmers in remote areas may have limited access to fuel, making this technology impractical to them. As is the case with soil solarization, the practicality and success of weed flaming also requires further studies on cost-benefit ratios before suggesting this technology to smallholder farmers. Due to the fire risk, other thermal weed control methods, such as weed steaming, might be more applicable to the context of southern Africa.

\subsubsection{Weed steaming}

A third option for thermal weed control that has mainly been explored for horticultural crops is weed steaming, whereby a steam generator (usually fueled by diesel) heats the soil to temperatures that are lethal to weeds, usually between 60 and $80{ }^{\circ} \mathrm{C}$ for 20 to $30 \mathrm{~min}$ (Elsgaard et al. 2010; Melander et al. 2013; Samtani et al. 2011). A study on strawberry fields in California found that steaming the soil at $70{ }^{\circ} \mathrm{C}$ for $20 \mathrm{~min}$ resulted in weed control efficacy comparable to that of a methyl bromide (67\%) and chloropicrin (33\%) treatment (Samtani et al. 2011). A controlled environment experiment in Italy found that weed steaming significantly reduced the emergence of some (Alopecurus myosuroides Huds. and Fallopia convolvulus L. Á. Löve), but not all (Matricaria chamomilla L.) weed species.

Use of weed steaming by smallholder farmers in southern Africa is most likely to be hindered by the high energy demands: even band-steaming, a less energy-intensive method of weed steaming, can require $8000 \mathrm{~L} \mathrm{ha}^{-1}$ of water and $570 \mathrm{~L} \mathrm{ha}^{-1}$ of fuel (Melander and Kristensen 2011). One alternative which may prove less costly is to target weeds in the early days of establishment, as in a study conducted by Kolberg and Wiles (2002), which found that steaming seedlings resulted in similar control of common lambsquarters (Chenopodium album L.) and redroot pigweed (Amaranthus retroflexus L.) as glyphosate treatments. The authors found that steaming was not an effective control method at the anthesis stage; farmers would therefore need to be trained in correct timing to reap the benefits of weed steaming. The efficacy of weed steaming may be hindered in CA systems due to the presence of crop residues, which would need to be taken into consideration before promoting the technology. Nevertheless, the weed steaming presents itself as a safer alternative to weed flaming and merits further study on how fuel and water consumption of such technology might be reduced and how it might be used to most effectively target weed species.

Soil solarization, weed flaming, and weed steaming are alternative options especially in horticulture crops, although they are yet not commonly used in sub-Saharan Africa. While all three methods can possibly be used for successful weed suppression in smallholder CA systems, they must be further 
studied and affordable options must be available before being recommended to farmers.

\subsection{Chemical control}

The success of CA systems has largely been attributed to the availability of chemical weed control methods (Swenson and Moore 2009). While labor demands can decrease by up to $90 \%$ as a result of herbicide use (Gianessi et al. 2009), herbicide-resistant weed species and negative environmental impacts from herbicide use (Norsworthy et al. 2012) underscore the importance of responsible use of chemical control methods to successfully control weed populations. The following section focuses on herbicide application and seed coatings for weed control and how they can be used effectively without compromising local agroecosystems.

\subsubsection{Herbicides}

Herbicide application has been critical to the success of CA systems throughout the Americas and Australia (Llewellyn et al. 2012; Moyer et al. 1994). When glyphosate prices decreased after Monsato's patent had expired, the incentive for herbicide use increased and unrestricted use has led to concerns about herbicide-resistant weed species (Bajwa 2014). An integrated weed control approach should guide herbicide use, including proper timing of herbicide applications and appropriate application rates (Norsworthy et al. 2012). Obstacles to herbicide access and application, such as local availability, price, and proper and safe handling of chemicals must be addressed through training by extension agents and researchers.

In a study of the effects of herbicide application in CA systems in Zimbabwe, Muoni et al. (2014) found that effective weed control including herbicides can gradually reduce weed pressure over the course of several years (see Fig. 4). This implies that, in the absence of adequate labor, intensive herbicide use would be necessary during the first 3 or 4 years. Thereafter, weeds could be more effectively controlled using mechanical or cultural methods. The authors also noted that combinations of contact and residual herbicides, such as atrazine, tended to be more effective against annual grasses and broadleaf species than paraquat or glyphosate alone. However, residual herbicides can only be used on specific crops and its use must be carefully considered (Ibid.). Factors such as weed density, dominant species, and farmer knowledge would need to be considered when establishing an herbicide application program. Chauhan et al. (2012) additionally suggest using cover crops to support herbicide application; by using a non-selective herbicide such as glyphosate, the cover crop is killed and used as a mulch, thereby limiting weed germination and growth.
One of the main challenges of herbicide application for smallholder farmers in Africa is the lack of access to inputs and cash by smallholder farmers (Giller et al. 2009; Andersson and D'Souza 2014). Women and female-led households in particular are even more disadvantaged when accessing herbicides due to their status and role in fund allocation in the households, thereby reducing their ability to effectively use this technology (Nyanga et al. 2012). Access to herbicides could be increased through targeted support programs, such as smart subsidies (Ngwira et al. 2014; Norsworthy et al. 2012). Additionally, governments could encourage local production of generic versions of non-patented herbicides like glyphosate, which would improve access and potentially lead to lower prices (Little 2010) although yellow phosphorous, one of the critical ingredients of glyphosate, has its main deposits in China, which limits local manufacturing in Africa. For such an initiative to be successful, herbicide quality and safety would need to be guaranteed through the creation of testing laboratories and enforced quality standards.

However, increased access should not lead to irresponsible use of herbicides. As an important pre-requisite, extension agents must be trained in herbicide use and application in order to show farmers how to optimize input use and limit potential negative impacts on the environment and human health (Thierfelder and Wall 2015) by using applicators and protective clothing, such as that shown in Figs. 5 and 6. While herbicide application is the most effective method of weed suppression for CA systems (see Table 4), its use must be carefully monitored by the farmer in order to reap the benefits without compromising the positive ecological impacts of CA (Bajwa 2014).

Herbicide efficiency can be enhanced by different application methods, including weed wipers. However, this technology is not further discussed in this paper due to several challenges in using it. Within the context of smallholder farmers in Zimbabwe, weed wipers were found to be difficult to control (in terms of herbicide flow) and not particularly durable (see Fig. 7). In addition, they were easily contaminated by the user and were rendered inefficient upon touching the soil.

\subsubsection{Seed coating}

The use of herbicide-resistant seeds may facilitate herbicide use, although this technology must first be made available to smallholder farmers (Kanampiu et al. 2003). Use of imazapyr (2-[4,5-dihydro- 4-methyl-4-(1-methylethyl)-5-oxo-1Himidazol-2-yl]-3-pyridinecarboxylic acid) and pyrithiobac (2-chloro-6-[(4,6-dimethoxypyrimidin-2-yl)sulfanyl]benzoic acid) seed coatings on herbicide-resistant maize (Zea mays L.) seeds was found to be successful against Striga hermonthica (Del.) and S. asiatica (L.) in field trials in Malawi and Zimbabwe and resulted in increased maize yields (Kanampiu et al. 2003). Kabambe et al. (2008) similarly found 
Fig. 4 Impacts of six weed control strategies: manual weeding, paraquat plus manual weeding, glyphosate plus manual weeding, atrazine plus manual weeding, atrazine + glyphosate + manual weeding, and atrazine + glyphosate + metolachlor plus manual weeding on weed density (in $\mathrm{m}^{-2}$ ). Weed densities gradually decreased over time, regardless of the weed suppression strategy used. Weed densities were significantly lower in the first season for the atrazine + glyphosate + metolachlor plus manual weeding treatment, which could indicate that farmers would profit from implementing a more aggressive herbicide strategy initially. Source: Adapted from Muoni et al. (2014)

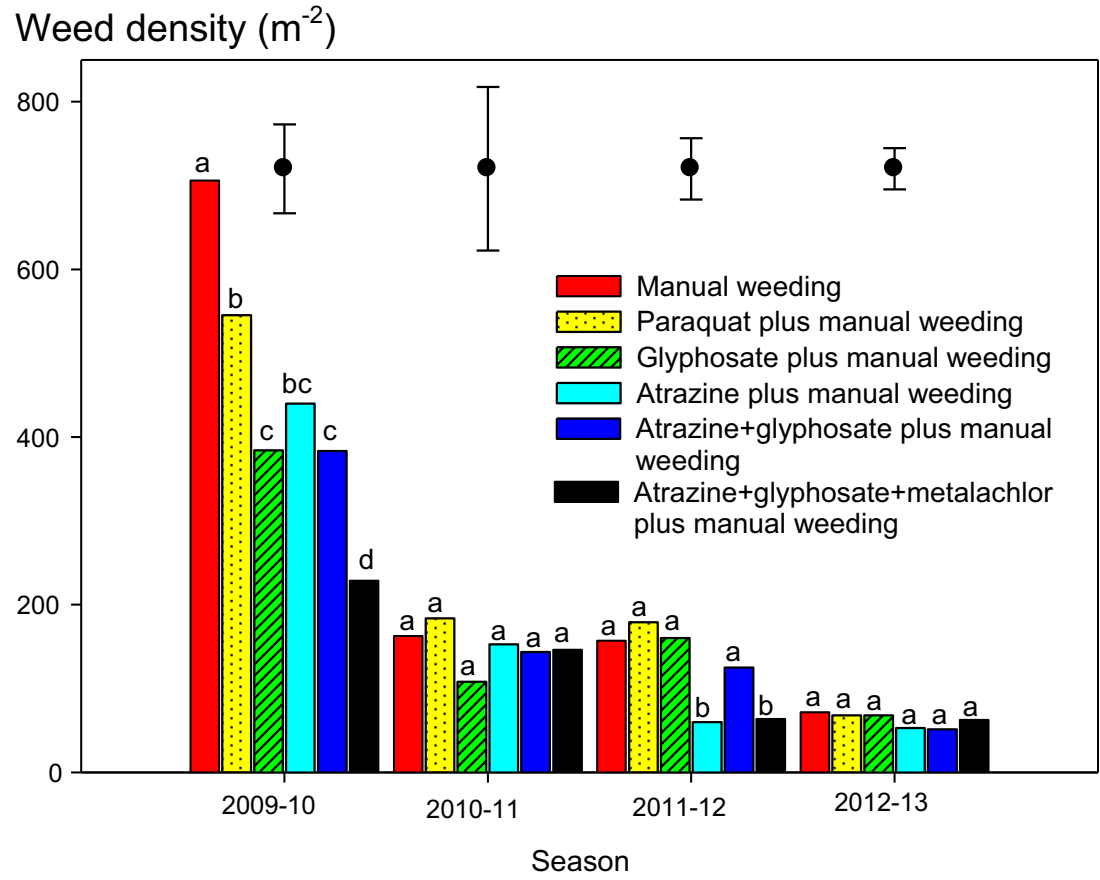

that maize seed coating with 30 to $45 \mathrm{~g} \mathrm{ha}^{-1}$ imazapyr resulted in significantly lower Striga counts 65 days after planting. The researchers also found no residual effects on non-herbicideresistant maize seeds in the following seasons. Seed coatings therefore appear to be a more targeted and an effective approach to combatting certain parasitic weed species (see Table 5), although the impacts of seed coatings on other important weed and crop species would need to be studied. While herbicide resistance can be induced through genetic modification, imazapyr-resistant (IR) maize was developed through conventional breeding methods (Mwangi et al. 2015), thereby making this technique more acceptable to

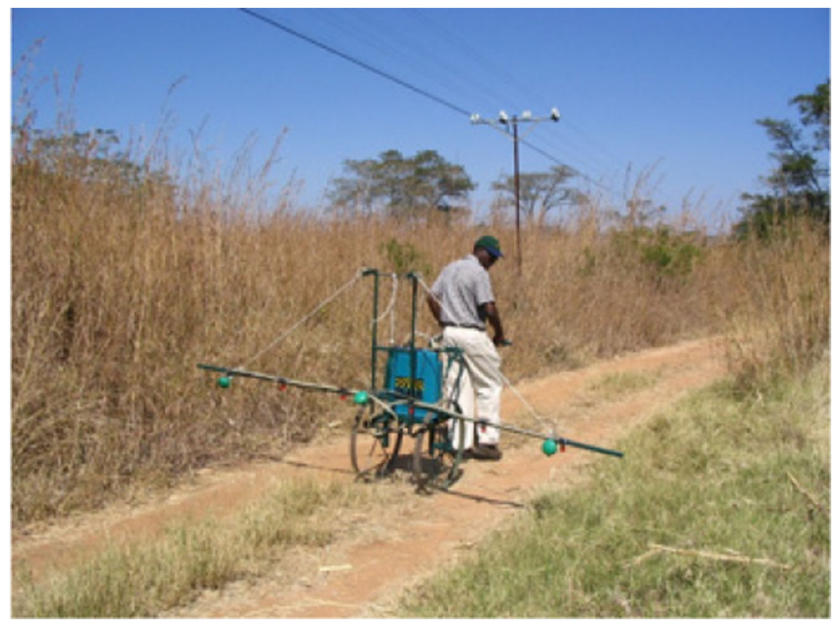

Fig. 5 A hand-pulled six-nozzle sprayer for herbicide application. This equipment is relatively inexpensive and allows for faster application. Photo credit: Christian Thierfelder, CIMMYT farmers and governments reticent or unable to use genetically modified crops.

In summary, chemical weed control is an important tool for many farmers adopting CA, but smallholder access to herbicides and seed coating technologies must be improved. In households where farmers do not place a monetary value on

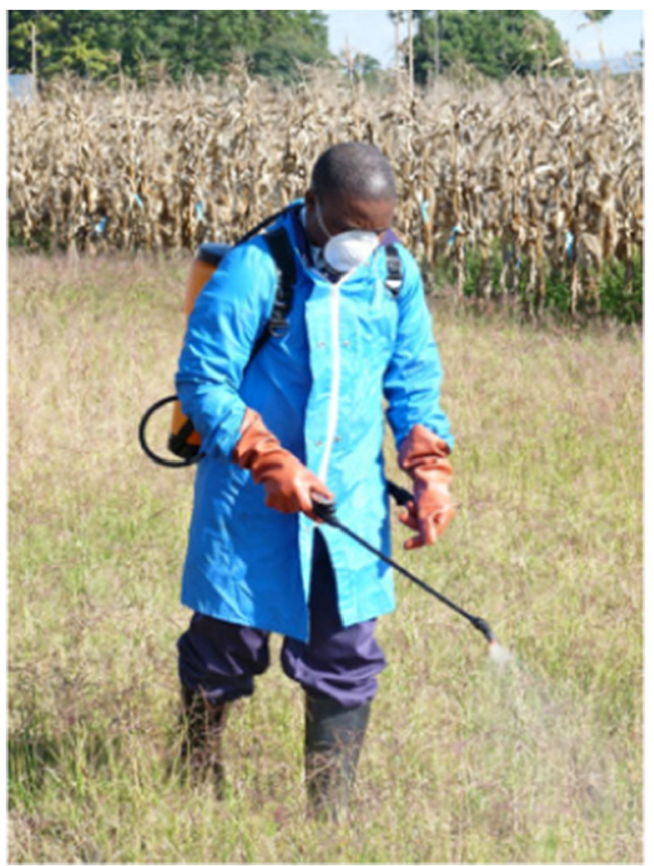

Fig. 6 A single nozzle knapsack sprayer to apply common herbicides in farmers' fields. Farmer training is an important aspect of herbicide promotion as incorrect use may lead to health problems or damage crops. Extension agents may provide this service to smallholder farmers. Photo credit: Christian Thierfelder, CIMMYT 
Table 4 Weed suppression rates (in percent) of different glyphosate-based herbicides in conventional tillage (CVT) and zero tillage (ZT) systems in maize fields in eastern Kenya

\begin{tabular}{lllllc}
\hline Treatment & $\begin{array}{l}\text { Herbicide application } \\
\text { rate }\left(\mathrm{L} \mathrm{ha}^{-1}\right)\end{array}$ & $\begin{array}{l}\text { Weeding/tillage } \\
\text { method }\end{array}$ & $\begin{array}{l}\text { Percent (\%) } \\
\mathrm{WS}^{1}\end{array}$ & $\begin{array}{l}\text { Percent (\%) } \\
\mathrm{WS}^{2}\end{array}$ & $\begin{array}{l}\text { Percent (\%) } \\
\mathrm{WS}^{3}\end{array}$ \\
\hline RWMX & 3.0 & ZT & $66.0^{\mathrm{b}}$ & $96.3^{\mathrm{a}}$ & $67.5^{\mathrm{ab}}$ \\
Un-weeded control & N/A & No Till & $0.0^{\mathrm{d}}$ & $0.0^{\mathrm{d}}$ & $0.0^{\mathrm{d}}$ \\
CVT & N/A & CVT & $88.5^{\mathrm{a}}$ & $35.0^{\mathrm{a}}$ & $91.8^{\mathrm{a}}$ \\
RWMX & 2.5 & ZT & $59.0^{\mathrm{b}}$ & $89.5^{\mathrm{b}}$ & $83.3^{\mathrm{b}}$ \\
RTB & 2.5 & ZT & $58.8^{\mathrm{b}}$ & $94.8^{\mathrm{ab}}$ & $89.0^{\mathrm{ab}}$ \\
RWMX & 1.5 & ZT & $49.5^{\mathrm{c}}$ & $82.8^{\mathrm{c}}$ & $75.3^{\mathrm{c}}$ \\
Mean & - & - & 53.6 & 66.4 & $71.1^{1}$ \\
LSD $(0.05)$ & - & - & 9.2 & 5.3 & 5.8 \\
\%CV & - & - & 11.4 & 5.3 & 5.4 \\
\hline
\end{tabular}

Means with the same superscript letter are not significantly different at a $\mathrm{p} \leq 0.05$ level. Source: Micheni et al. (2014), p. 264

$R W M X$ Roundup Weathermax, $R T B$ roundup turbo, $N / A$ not applicable, $W S^{l}$ weed suppression event 1 observed 1 month after glyphosate herbicide application, $W S^{2}$ weed suppression event 2 observed 2.5 months after glyphosate herbicide application, $W S^{3}$ weed suppression event 3 observed 3.5 months after glyphosate herbicide application, $C V$ coefficient of variation, $L S D$ least significant difference farm labor (predominantly that of women and children), purchasing herbicides and spraying equipment comes with additional costs, making the technology less feasible especially if farmers are cash constrained. Nevertheless, herbicides can effectively suppress weeds, especially those that cannot be controlled with manual or mechanical approaches (e.g., couch grass). However, farmers need to be trained in their safe use to prevent improper application that may damage crops

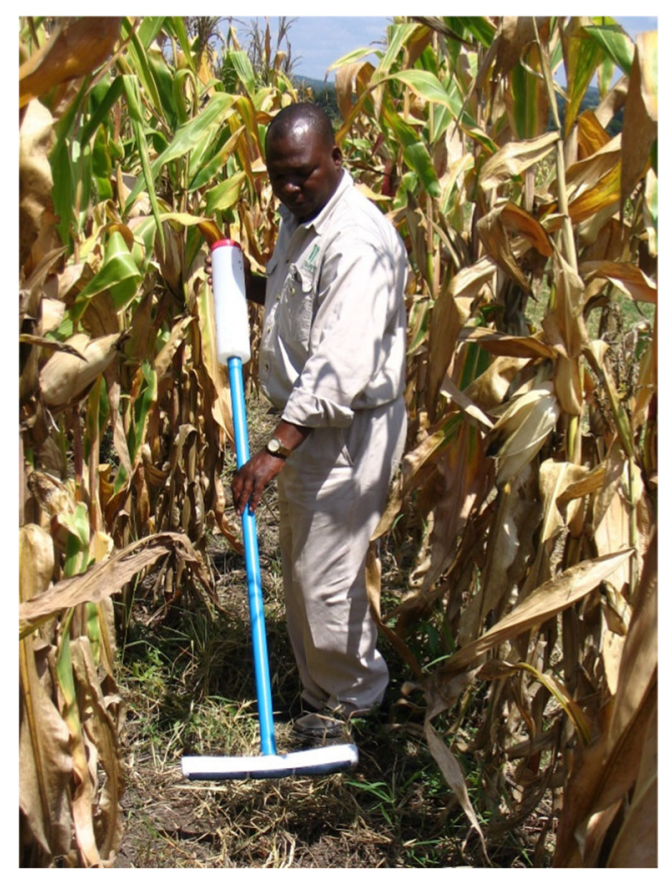

Fig. 7 An example of weed wiping technology in a maize field in Zimbabwe. This handheld weed wiper may be an appropriate tool for smallholder farmers to for more precise pesticide application. However, the challenges with its application in the field make it a less attractive option for smallholders. Photo credit: Christian Thierfelder, CIMMYT
(Mtambanengwe et al. 2015), reduce herbicide-resistance, and avoid negative environmental consequences. Herbicide seed coatings can provide additional control against parasitic weed species such as Striga spp., although they are ineffective against non-parasitic weeds.

\subsection{Cultural control}

Cultural weed control uses cropping systems to reduce weed pressure. In many instances, cultural control methods are cheaper than chemical control methods and provide additional benefits to the soil, such as the addition of organic matter and biologically fixed nitrogen (Norsworthy et al. 2012). The following chapter examines the benefits and drawbacks of four cultural control methods: enhanced crop competition through the use of planting and fertilization calendars, the retention of crop residues to suppress emerging weeds, intercropping systems to improve crop competition, crop rotations, and harvest weed seed control to reduce species-specific weed pressures.

\subsubsection{Enhanced crop competition using planting and fertilization calendars}

Crop competition is an inexpensive weed control strategy suited to smallholder farmers who are either unable to access herbicides or produce sufficient biomass for crop residue retention as a weed suppression tool (Mhlanga et al. 2016a, b). Crop competition can be enhanced through increased population where possible and the development of planting and fertilization calendars to assist smallholder farmers in implementing management practices at times that optimize competition between crop and weed species (Kumar et al. 2013). Increasing planting density in maize can also increase 
Table 5 Effect of imazapyr seed coating on Striga weed count and number of flowering plants

\begin{tabular}{|c|c|c|c|c|c|}
\hline Treatment & $\begin{array}{l}\text { Striga count } \\
69 \text { DAP }\end{array}$ & $\begin{array}{l}\text { Striga count } \\
81 \text { DAP }\end{array}$ & $\begin{array}{l}\text { Striga count } \\
\text { 86 DAP }\end{array}$ & $\begin{array}{l}\text { Striga count } \\
103 \text { DAP }\end{array}$ & $\begin{array}{l}\text { Number flowered } \\
\text { Striga } 103 \text { DAP }\end{array}$ \\
\hline $1=$ No seed treatment & 4.8 & 15.9 & 14.7 & 62.9 & 6.2 \\
\hline $2=$ Imazapyr $15 \mathrm{~g} \mathrm{ha}^{-1}$, drench & 0.1 & 2.6 & 4.9 & 35.8 & 0.1 \\
\hline $3=$ Imazapyr $30 \mathrm{~g} \mathrm{ha}^{-1}$, drench & 0.9 & 0.1 & 1.0 & 20.7 & 0.1 \\
\hline $4=$ Imazapyr $45 \mathrm{~g} \mathrm{ha}^{-1}$, drench & 0.0 & 0.1 & 0.7 & 30.2 & 0.0 \\
\hline $5=$ Imazapyr $15 \mathrm{~g} \mathrm{ha}^{-1}$, prime & 0.7 & 6.4 & 6.6 & 48.0 & 0.7 \\
\hline $6=$ Imazapyr $30 \mathrm{~g} \mathrm{ha}^{-1}$, prime & 0.1 & 1.2 & 1.8 & 31.0 & 0.2 \\
\hline 7 = Imazapyr $45 \mathrm{~g} \mathrm{ha}^{-1}$, prime & 0.2 & 0.0 & 1.3 & 29.5 & 0.3 \\
\hline $8=$ Imazapyr $15 \mathrm{~g} \mathrm{ha}^{-1}$, coat & 0.0 & 1.9 & 1.3 & 33.0 & 0.3 \\
\hline $9=$ Imazapyr $30 \mathrm{~g} \mathrm{ha}^{-1}$, coat & 0.1 & 0.8 & 2.0 & 25.6 & 0.3 \\
\hline $10=$ Imazapyr $45 \mathrm{~g} \mathrm{ha}^{-1}$, coat & 0.1 & 0.1 & 1.4 & 25.4 & 0.4 \\
\hline Mean & 0.7 & 2.9 & 2.19 & 34.2 & 0.8 \\
\hline$P$ level & 0.014 & 0.003 & 0.009 & 0.207 & 0.06 \\
\hline LSD 5\% & 2.40 & 6.97 & 6.7 & 29.08 & 0.06 \\
\hline $\mathrm{CV} \%$ & 196 & 140 & 107 & 51 & 260 \\
\hline
\end{tabular}

In all treatments, Striga counts were reduced compared to the control (although not significantly for all treatments by 103 days after planting). Source: Kabambe et al. (2008), p. 3296

$L S D$ least significant difference, $C V$ coefficient of variation

crop competitiveness with weed species (Mashingaidze et al. 2009a, b; Mhlanga et al. 2016a, b), although water resources are critical in higher density stands, limiting their use in semiarid areas of southern Africa (see Fig. 8).

Timely planting is an essential element of weed management in CA systems (Gatere et al. 2013). Chauhan et al. (2012) found that earlier planting may allow crop seeds to outgrow weed species that would otherwise be in direct competition for water and nutrients. A study of no-tillage rice-wheat systems in India found a $68-80 \%$ reduction in littleseed canarygrass (Phalaris minor Retz.) population when wheat was sown early (Kumar et al. 2013). Another study conducted in the semi-arid northern Great Plains of the USA determined that sowing barley seeds 4-6 weeks earlier than normal planting dates resulted in lower weed seed production and biomass (Lenssen 2008). Changes in planting times may, however, be less attractive to farmers if dates are largely determined by rainfall patterns, cropping season duration and labor availability (Norsworthy et al. 2012), as is often the case in semi-arid southern Africa. Changes in the timing of other management practices, such as fertilization, may provide a more feasible alternative.

Studies on the effects of fertilization on crop competition are contradictory; results depend largely on both the crop and predominant weed species (Walker and Buchanan 1982). Careful timing of fertilization to optimize plant growth and limit nutrient exploitation by weed species can provide crops with a competitive advantage over weeds (Norsworthy et al. 2012). Earlier planting in conjunction with N-fertilizer application at the stem elongation phase of winter wheat was found to reduce Veronica hederifolia L. biomass and while bolstering crop biomass production compared to $\mathrm{N}$-fertilizer application at the tillering stage (Liebman and Davis 2000). Conversely, a study on weed competition with maize hybrids found that lower $\mathrm{N}$-fertilization resulted in higher maize yields and reduced weed interference (Tollenaar et al. 1994). Not only the type of fertilizer applied, but also the method in which it is applied, can play a significant role in weed suppression. Di Tomaso (1995) cited several studies which found that broadcast application of fertilizers did little to suppress weed growth, while surface banding and deep banding in particular of fertilizer allowed crops to out-compete weeds. Therefore, more detailed studies and observations of weed population trends related to changes in planting and fertilization dates are necessary prior to making recommendations to farmers.

\subsubsection{Crop residue retention}

Several studies have examined the effectiveness of crop residue retention as a method of weed suppression (Chauhan et al. 2012; Liebl et al. 1992; N. Mashingaidze et al. 2009a, b). Chauhan et al. (2012) highlight the varied success of crop residues as weed suppressants: while some weed populations respond immediately to increasing quantities of mulch, other weeds seemingly benefit from the increased soil moisture resulting from small quantities of mulch and are only effectively managed when large quantities of residue are left on the field to smother the weeds. A study by Teasdale et al. (1991) found that increased percentage of residue cover (rye [Secale cereal L.] or hairy vetch [Vicia villosa Roth]) resulted 
Fig. 8 Effect of three different cultivars, maize plant densities, and two planting arrangements (in rows, indicated by rhombus $=$ conventional row planting and in a grid, indicated by circle $=$ grid pattern planting) on total weed biomass yield (collected at 1 month after sowing the maize and at maize harvest) over two seasons. In all cases, weed density decreased with maize between 5 and 7 maize plants $\mathrm{m}^{-2}$, while two cultivars (Novillero and Amarillo ICA V-305) continued to suppress weed biomass production at 10.5 plants $\mathrm{m}^{-2}$. Data source: Marin and Weiner (2014). Figure Source: Mhlanga et al. (2016a)
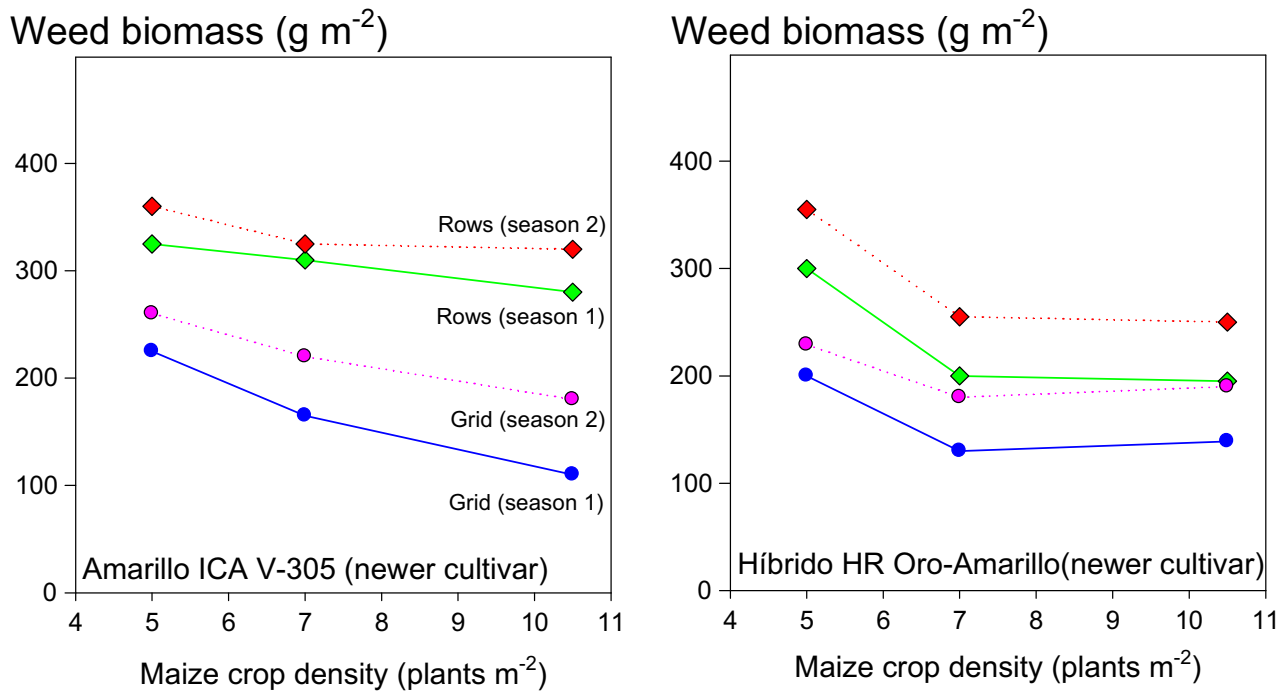

in lower weed density, as determined in a study from Maryland, USA.

Recommended mulch application rates vary widely, ranging from 3 to $20 \mathrm{t} \mathrm{ha}^{-1}$ (Christoffoleti et al. 2007; Mashingaidze et al. 2012; Wall et al. 2014) depending on agroecology and soil type. Crop residues as weed control may therefore be particularly problematic for smallholder farmers in semi-arid areas as they often lack sufficient quantities of biomass to create a residue layer that effectively suppresses weed growth (Vanlauwe et al. 2014). This issue could be resolved by selecting species specifically for their biomass production potential. For example, Chauhan et al. (2012) suggest the use of cereal crop residue as it produces greater amounts of biomass compared to oilseed crops. Cereal crop residues can thus have greater weed suppression effects than oilseed crops or leguminous crops with creeping growth habits (see Fig. 9).

Although crop residue retention is an important element of $\mathrm{CA}$ and imparts many weed-suppressing benefits, the residues may interfere with herbicidal action, thereby rendering herbicides less effective (Bajwa 2014). As previously mentioned, crop residues also make the use of soil rippers and other cultivators more tedious and ineffective (Erenstein 2003). The efficacy of crop residue retention as a weed suppression tool may be further limited by the morphology of the residue: maize stalks were found to be less effective in controlling weed populations than maize leaves as they hindered farmers' abilities to hand-hoe weed throughout the remainder of the season (Vogel 1994). Others recommend the use of live or dead mulch from green manure cover crops to suppress weeds (Mhlanga et al. 2015a, b). Sunnhemp (Crotalaria juncea L.), for example, was shown to have promising weed suppression potential under CA in Zambia. The canopy of sunnhemp closes so rapidly that weeds are not able to grow due to competition for light.

Crop residue retention as a weed control mechanism can be further enhanced by specifically selecting crop species for their competitiveness with other weed species. Research by 
Weed above ground biomass ( $\mathrm{g} \mathrm{m}^{-2}$ of $\left.\mathrm{DM}\right)$

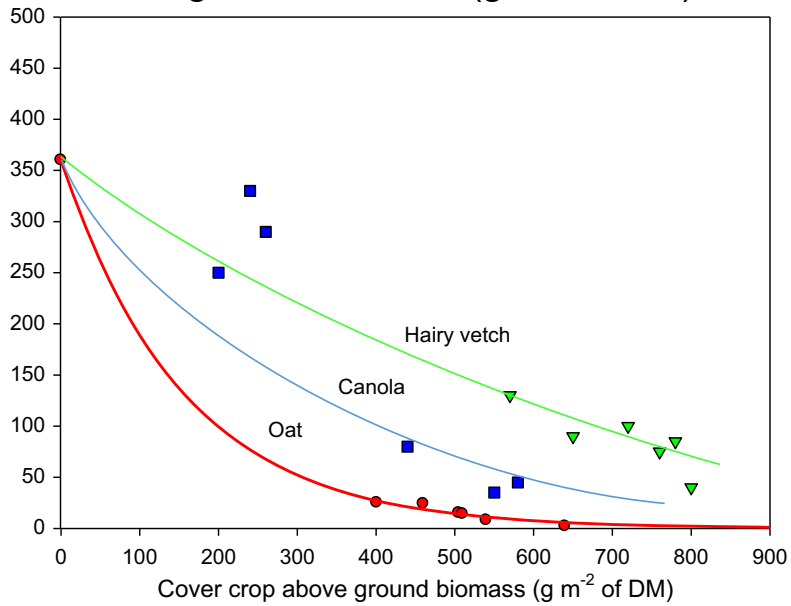

Fig. 9 Relationship between cover crop biomass and weed aboveground biomass for three crop species: oat, canola, and hairy vetch. Oats tended to suppress weed growth more effectively than canola or hairy vetch. Effectiveness of cover crops in suppressing weeds was largely dependent upon the cover crop's aboveground biomass. Source: Radicetti et al. (2013), p. 112

Flower et al. (2012) showed that the use of black oat (Avena strigosa Schreb.) as a cover crop in a drought-prone area of Australia was effective in suppressing weed growth in addition to being quick-growing and producing large quantities of biomass. Selecting drought-resistant, high biomass-producing cover crops (such as lablab (Lablab purpureus L.), velvet bean (Mucuna pruriens L.), and sunnhemp and utilizing them as mulch could be a beneficial tool for weed suppression under CA. Farmers could take advantage of crops with allelopathic properties, such as black sunnhemp ( $C$. juncea $\mathrm{L}$.), which have been found to successfully suppress weeds over several seasons in CA systems in Zimbabwe (Mhlanga et al. 2015a). Sorghum (Sorghum bicolor L.) has been used as a cover crop in CA systems in Brazil (Christoffoleti et al. 2007), largely due to its ability to suppress weed populations through the release of the allelochemical sorgoleone (Dayan et al. 2010). Another study in Brazil found that using sorghum, velvet bean, Crotalaria spectabilis Roth, Crotalaria ochroleuca G. Don., and Mucuna aterrima Piper \& Tracy as green manure decreased both the dry matter weight and the number of the weed species Hyptis lophanta Ben. and Amaranthus spinosus L. (Erasmo et al. 2004), the latter being a very common weed in southern Africa.

\subsubsection{Intercropping}

Several studies mention intercropping as an effective weed suppression tool (Zimdahl 1993; Carruthers et al. 1998). The addition of another crop species between rows can lead to smothering of and greater competition with weed species, minimizing their impact on the main crop being cultivated (Carlson 2008), although crop-crop competition is also possible (Mafongoya et al. 2006; Thierfelder et al. 2012a). Increasing the diversity of crops being grown in a single area can help reduce pressure from weeds that are host-specific (Carlson 2008). In addition, intercropping systems can supply extra food (and protein) for human consumption or forage for animals. Intercropping with leguminous plants in particular provides the added benefit of increased soil fertility through nitrogen fixation (Mafongoya et al. 2006).

Low rainfall can be a significant impediment to successful intercropping in semi-arid regions of southern Africa (ZegadaLizarazu et al. 2006). Species with low rainfall requirements and limited competitiveness with main crops should thus be selected for intercropping systems. Drought-tolerant legumes such as cowpea (Vigna unguiculata Walp), lablab, pigeonpea (Cajanus cajan [L.] Millsp.), and velvet bean have been shown to successfully suppress weed populations (Graham and Vance 2003; Mhlanga et al. 2016a, b) and would be suitable for smallholder rainfed farming systems.

Cowpea-maize intercropping systems reduced the necessary number of weedings to maintain yields as compared to solecropping systems in semi-arid Zambia (Simunji et al. 2011). Intercropping maize with lablab in a semi-arid area of Kenya reduced the weed density of Portulaca quadrifida L. and Paraknoxia parviflora L. but increased E. indica L. density (Mwangi et al. 2015). Although overall weed density was not affected, the study found that the density of broadleaf weed species was negatively affected by lablab intercropping, while annual species were positively affected (Ibid). Field trials in Pakistan indicated that intercropping of sorghum and sesame significantly reduced population and biomass of purple nutsedge (C. rotundus L.) in cotton production systems (Iqbal et al. 2007). Similarly, a study by Mkamilo (2004) in a semi-arid area of Tanzania found that maize-sesame intercrop systems successfully suppressed weed populations. The same study found that while the sesame competed with the maize, the reduced impact of weed pressure resulted in similar yields as maize monocrop systems. Intercropping systems with leguminous species are particularly beneficial for farmers struggling with $S$. asiatica (L.) Kuntze or S. hermonthica (Del.) Benth. (generally referred to as Striga) infestations: one 7-year study in Kenya determined that several edible legume species, including crotalaria and groundnut (Arachis hypogaea L.), reduced Striga hermonthica emergence by up to $35 \%$ (Midega et al. 2014). A more recent study by Midega et al. (2017) indicated that drought-tolerant Desmodium [Desmodium uncinatum (Jacq.) DC. and Desmodium intortum (Mill.) Urb.] species significantly reduced Striga incidence in sorghum-Desmodium intercropping systems. Desmodium provides the additional benefit of forage for animals, which could be an important incentive in smallholder mixed farming systems.

The success of intercropping as a weed management practice has been mixed and is largely contingent upon crop species used and prevalent weed species (Carruthers et al. 1998; 
Iqbal et al. 2007). An understanding of weed species composition and intercrop competition at farm and local levels is therefore essential prior to recommending certain intercropping systems. Use of intercropping for weed suppression in drought prone areas may be better-suited in the years following CA adoption, as higher soil moisture content would likely favor multi-crop systems.

\subsubsection{Crop rotations}

Weed competition with crops can be limited by maintaining live soil cover through crop rotations, thereby making weed establishment more difficult (Blackshaw et al. 2008; Shrestha et al. 2002). Cover crop rotations with leguminous species provide the additional benefit of dietary diversity (for both animals and humans) as well as biological nitrogen fixation (Govaerts et al. 2009; Lahmar and Triomphe 2007). While the success of crop rotation as a weed management tool varies throughout the literature, it appears to be quite effective in semi-arid regions. However, weed suppression and other soil benefits may not be apparent during the first years following transition to rotational systems (Sakala et al. 2000; Thierfelder et al. 2012a, b).

A study by Mhlanga et al. (2016a) in Zimbabwe showed that maize-cover crop systems using leguminous species decreased weed densities. However, the success of these crop rotation systems is largely contingent on the type of cover crop used. The same study found higher weed densities under cover crops with sparse growth habits (e.g., pigeonpea) compared to species such as velvet bean, which are more competitive with weed species due to greater overall ground cover (Ibid.). While other crop rotation systems using alfalfa (Medicago sativa L.) and red clover (Trifolium pretense L.) are also attributed to weed density reductions in semi-arid regions (Blackshaw et al. 2008), their high water demands in the offseason make them an unrealistic option for smallholder farmers in southern Africa lacking access to irrigation systems.

Some farmers are reluctant to adopt crop rotation systems due to a reduction in area allocated to maize production, the staple crop in southern Africa (Dowswell et al. 1996). The short cropping season in semi-arid regions of southern Africa (usually November to April) additionally hinders adoption of some crop rotation systems (Mupangwa et al. 2016); they must instead rotate on a yearly basis. However, the benefits of crop rotation as a weed management and soil amelioration tool can outweigh perceived risks from switching to a rotational system, once farmers observe the improvements to their soils (Thierfelder and Wall 2010b). The same constraints limiting intercropping are relevant in crop rotations: predominant weed species would have to be studied and crop rotation species would need to be selected based on their droughttolerance and weed-suppressing abilities. In addition, introduction of crop rotation systems is often limited by a lack of economic incentives, particularly if the crop does not provide an immediate use as food or animal fodder (Thierfelder et al. 2012a, b).

Intercropping, crop rotations, and crop residue retention are three commonly used cultural weed control methods and several studies have been conducted in Zimbabwe regarding the impacts of these cultural practices on weed populations (see Table 6). The lack of studies in other areas in southern Africa further highlights the importance of research in this area to help farmers better implement these strategies in the local context. Nevertheless, the positive results with these cultural control methods in Zimbabwe and Malawi are encouraging in their potential application throughout other areas of southern Africa.

\subsubsection{Harvest weed seed control}

Due to increased resistance to commonly used herbicides, researchers in Australia have been using several innovative non-chemical methods: one of the most successful of these methods is harvest weed seed control (HWSC), whereby weed seeds are destroyed during harvest, thus reducing the weed seed bank (Stokstad 2013). In Australian wheat cropping systems, a large portion of major weed species reach maturity at the same time as the wheat. By managing weed seeds during harvest time, farmers eliminate large portions of the weed seed bank while harvesting their crop (Norsworthy et al. 2016). By attaching chaff carts to harvesters to collect weed seeds for later destruction, burning windrows containing weed seeds and/or grinding weed seeds after harvest and then reapplying them to the fields, farmers can amplify the benefits of herbicide application and other weed control methods (Walsh et al. 2013).

To the authors' knowledge, no studies have yet been conducted on the potential of HWSC in southern Africa, particularly in the context of smallholder farmers. HWSC requires specially equipped machinery which may not be practical for small plots of land. Currently, HWSC technologies are far too expensive $(\$ 70,000$ AUD to $\$ 250,000$ ) to be in reach of smallholder farmers in southern Africa (Stokstad 2013), but research on small-scale weed seed harvesting methods could lead to an additional weed management for farmers. As with small, animal-drawn cultivators, production of small-scale weed seed harvesting equipment could be promoted within southern Africa to increase accessibility to farmers. A practice often promoted by NGOs in the region is to encourage farmers to conduct late season weed control and avoid weeds from setting seed. This can be done by hand pulling or shallow hoe weeding (e.g., scraping). However, this practice requires significant education of smallholder farmers as they often abandon field work after the crop has matured and late season weeding would be extra and unwanted labor. 


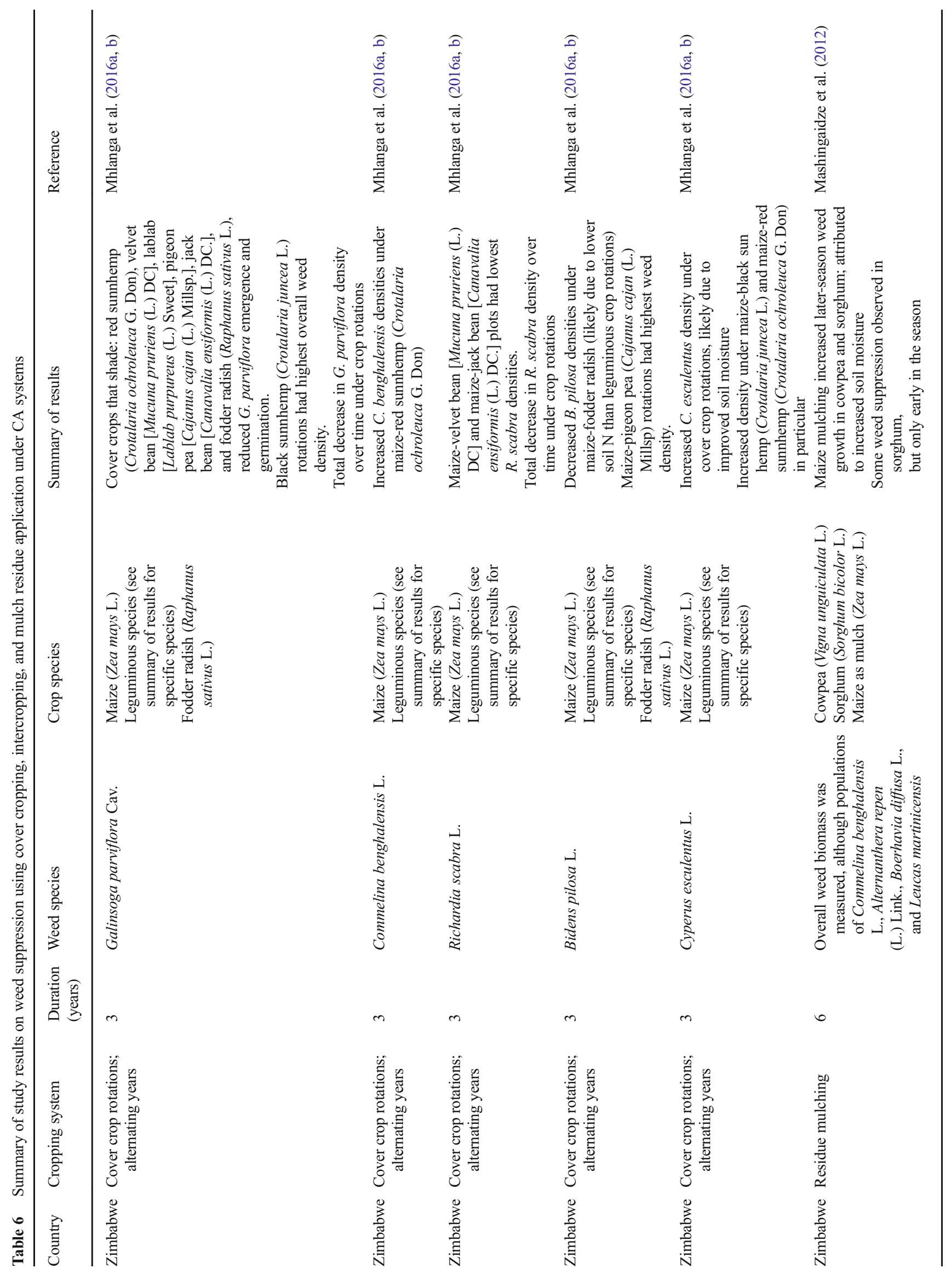




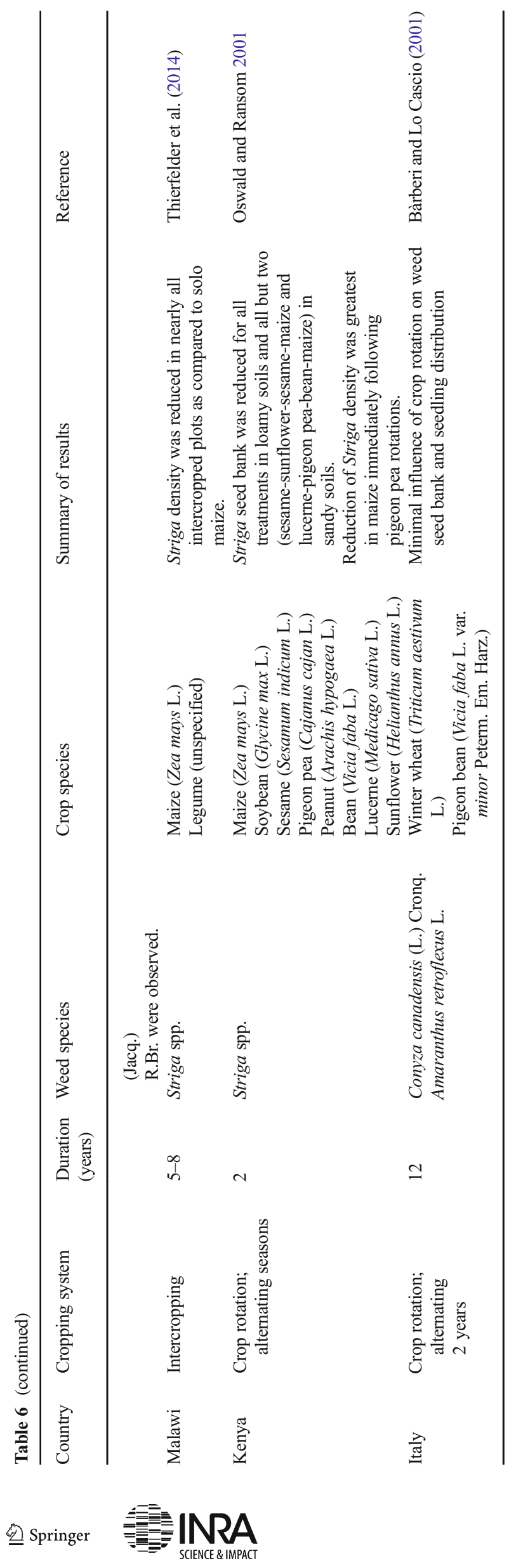

In summary, cultural weed management is one of the most cost-effective strategies used by smallholder farmers and provides an alternative to chemical control. Crop competition against weeds can be increased through the use of planting and fertilization calendars, which provide farmers with guidelines for optimal dates for enhancing competition. Crop residue retention through live or dead mulch and green manure cover crops can improve soil moisture and organic matter content in addition to smothering weeds. Intercropping and crop rotations diversify production to break weed cycles, although markets must be created for farmers to sell rotational crop species to compensate for reduced maize production. As was seen in Table 6, cultural control methods have the potential for farmers to relieve weed pressure while increasing crop diversity.

\section{Summary of weed control strategies}

Numerous studies have been conducted regarding the effectiveness of multiple weed management strategies under CA. Unfortunately, many of these studies have inconclusive or conflicting results, indicating that the success of weedsuppression strategies is largely contingent upon site, weed species, and farm management. It is therefore imperative that researchers and extension workers thoroughly examine a series of options that can be combined and tailored to smallholder farmers in semi-arid southern Africa based on farmer resources, farm size, crop and weed species, and farmer preferences. A combination of strategies that take local conditions and resources into account is therefore considered necessary. The changes in soil parameters as a result of CA implementation are also important. Because soil moisture and weed composition are likely to change over the years following CA adoption, the success of certain strategies may also change over time. Weed control strategies employed by smallholder farmers can be manual, mechanical, chemical, cultural, or a combination of practices, each with benefits and challenges (see Table 7). These different weed management strategies can then be applied spatially and temporally to adapt to these farm-level changes.

Initially, CA implementation in smallholder farms in southern Africa is more challenging without the use of herbicides, especially if aggressive grass or broadleaf weed species are present. However, herbicide application alone is not the answer to sustainable weed management for resource-poor smallholder farmers. Herbicide use could be an initial intervention for the first years of conversion until complicated weed species are under control, thereafter chemical control could be phased out. Herbicide use could also be reinforced by management practices that are pillars of $\mathrm{CA}$, such as permanent soil cover. This will help to suppress weeds while reaping the benefits of increased soil fertility. This 
Table 7 Benefits and challenges of proposed weed management strategies for smallholder farmers adopting CA systems in semi-arid regions of southern Africa

\begin{tabular}{|c|c|c|}
\hline Strategy & Benefits & Challenges \\
\hline Herbicide application & $\begin{array}{l}\text { Highly effective (Llewellyn et al. 2012; } \\
\text { Moyer et al. 1994) } \\
\text { Can reduce weed pressure over time } \\
\quad \text { (Muoni et al. 2014) } \\
\text { Reduces labor requirements (Muoni et al. 2014) }\end{array}$ & $\begin{array}{l}\text { Potential for environmental and human risks } \\
\text { (Arias-Estévez et al. 2008) } \\
\text { Proper training needed for use (Thierfelder and Wall 2015) } \\
\text { Potential for herbicide-resistant weeds (Norsworthy } \\
\text { et al. 2012) } \\
\text { Limited input availability in some areas (Giller et al. 2009) } \\
\text { May require several applications throughout the growing } \\
\text { season }\end{array}$ \\
\hline Seed coating & $\begin{array}{l}\text { Reduces amount of herbicide needed } \\
\quad \text { (Kabambe et al. 2008) } \\
\text { Highly effective (Kanampiu et al. 2003) } \\
\text { No residual effects on non-herbicide-resistant seeds } \\
\quad \text { (Kabambe et al. 2008) }\end{array}$ & $\begin{array}{l}\text { Only viable for parasitic weed species } \\
\text { Limited availability to farmers (Kanampiu et al. 2003) }\end{array}$ \\
\hline Manual weeding & $\begin{array}{l}\text { Low financial cost } \\
\text { Limited knowledge and skill required } \\
\text { Can reduce weed pressure over time if weeds are } \\
\text { removed before going to seed and properly } \\
\text { disposed of (Vogel 1994; Mashingaidze et al. 2012) }\end{array}$ & $\begin{array}{l}\text { High labor demands; frequent weeding necessary to be } \\
\text { effective (Mashingaidze et al. 2012; Nyamangara } \\
\text { et al. 2013) } \\
\text { Women often take on additional labor demands } \\
\text { (Giller et al. 2009) } \\
\text { Less effective than herbicide application (Gianessi } \\
\text { et al. 2009) }\end{array}$ \\
\hline $\begin{array}{l}\text { Animal traction } \\
\text { mechanical control }\end{array}$ & $\begin{array}{l}\text { Lower labor demands than manual weeding (Twomlow } \\
\text { and O’Neill 2003) } \\
\text { Inexpensive (Ekboir 2003) } \\
\text { Can be purchased collectively (Najafi and Torabi } \\
\text { Dastgerduei 2015) } \\
\text { May encourage local manufacturing sector (Sims et } \\
\text { al. 2012a, b) }\end{array}$ & $\begin{array}{l}\text { Reduced efficacy with large quantities of plant residues } \\
\text { (Thierfelder et al. 2014) }\end{array}$ \\
\hline Soil solarization & $\begin{array}{l}\text { Highly effective against weed seeds (Norsworthy et } \\
\text { al. 2012) } \\
\text { Added benefits of fungal disease and nematode } \\
\text { control (Stapleton and DeVay 1986) }\end{array}$ & $\begin{array}{l}\text { High cost } \\
\text { Environmental considerations, if not properly disposed of } \\
\text { No tradition of use in southern Africa } \\
\text { Only effective against weed seeds in the top soil layers } \\
\quad \text { (Johnson et al. 2007) }\end{array}$ \\
\hline Weed flaming & $\begin{array}{l}\text { Highly effective (up to } 88 \% \text { mortality) against weed } \\
\text { populations (Stepanovic et al. 2015) } \\
\text { Limited residual damage to crops (Stepanovic et al. 2015) }\end{array}$ & $\begin{array}{l}\text { Requires specialized knowledge of timing and equipment } \\
\text { handling } \\
\text { Flame risk } \\
\text { Fuel requirements may be too high for smallholder farmers } \\
\text { Not suitable for all crop species (Bond 2002) }\end{array}$ \\
\hline Weed steaming & Highly effective weed control (Samtani et al. 2011) & $\begin{array}{l}\text { Very high fuel and water requirements (Melander and } \\
\text { Kristensen 2011) }\end{array}$ \\
\hline Crop competition & $\begin{array}{l}\text { Leads to more efficient nitrogen use in addition to weed } \\
\text { control } \\
\text { Reduces reliance on herbicides (Mhlanga et al. 2016a, b) } \\
\text { Appropriate for farmers with insufficient biomass } \\
\text { production for residue retention (Mhlanga et } \\
\text { al. } 2016 \mathrm{a}, \mathrm{b})\end{array}$ & $\begin{array}{l}\text { Requires specialized knowledge of timing and weed } \\
\text { species growth patterns (Gatere et al. 2013; Walker and } \\
\text { Buchanan 1982) } \\
\text { Success may be limited by unpredictable rainfall patterns } \\
\text { and/or low labor availability (Norsworthy et al. 2012) }\end{array}$ \\
\hline $\begin{array}{l}\text { Planting and fertilization } \\
\text { calendars }\end{array}$ & Relatively inexpensive (Mhlanga et al. 2016a, b) & $\begin{array}{l}\text { Requires specialized knowledge } \\
\text { Very time-sensitive }\end{array}$ \\
\hline Intercropping & $\begin{array}{l}\text { Can provide additional food or fodder } \\
\text { Helps maintain soil cover } \\
\text { Can increase competitiveness with weed species and } \\
\text { reduce host-specific weed pressure (Carlson 2008) } \\
\text { Can improve soil fertility through N-fixation } \\
\text { (Mafongoya et al. 2006) }\end{array}$ & $\begin{array}{l}\text { Potential for crop-crop competition for resources } \\
\text { (particularly water) (Mafongoya et al. 2006; } \\
\text { Thierfelder et al. 2012a, b) }\end{array}$ \\
\hline Crop rotations & $\begin{array}{l}\text { Maintains permanent soil cover } \\
\text { May decrease weed densities (Mhlanga } \\
\quad \text { et al. } 2016 \mathrm{a}, \mathrm{b})\end{array}$ & $\begin{array}{l}\text { Reduces area planted with staple crops } \\
\text { Limited market availability of certain (Thierfelder et al. } \\
\text { 2012b) species (Thierfelder et al. 2012a, b) } \\
\text { Not all crop species effectively suppress weeds } \\
\text { (Mhlanga et al. 2016a, b) }\end{array}$ \\
\hline $\begin{array}{l}\text { Harvest weed } \\
\text { seed control }\end{array}$ & $\begin{array}{l}\text { Can lead to a decreased weed seed bank over } \\
\text { time (Norsworthy et al. 2016) }\end{array}$ & $\begin{array}{l}\text { Currently not adapted to smallholder farming systems } \\
\text { due to price and technology required (Stokstad 2013) }\end{array}$ \\
\hline
\end{tabular}


combination of conventional weed control methods with conservation-oriented practices could therefore prove to be a successful compromise for smallholder farmers. However, herbicides are not a mandatory pre-requisite for CA implementation and many examples from Malawi and Zimbabwe have shown that its implementation is possible without any herbicide use.

Case studies from Malawi and Zimbabwe also highlight the importance of determining weed management goals. By striving to minimize the yield and economic impacts of weed pressure rather than eliminating all weed species entirely, farmers may be able to manage weeds despite resource constraints. While weed population density may remain above levels found in conventional tillage systems during the first years, limiting weed impacts on crop yield should be a greater priority than complete weed control. One knowledge gap missing is seed bank dynamics, including dormancy and germination, of important weed species in semi-arid southern Africa. Gaining a deeper understanding of weed biology and ecology is crucial to developing targeted, effective control mechanisms for weed suppression.

\section{Conclusion}

Weed control is one of the greatest impediments for successful crop production and specifically for the application of CA systems in southern Africa. Without effective weed management and control strategies, successful adoption of CA in smallholder farming systems in semi-arid southern Africa is rather unlikely. While weeds are controlled in large-scale commercial agriculture systems in the Americas and Australia through regular and abundant herbicide use, this strategy is often not feasible for smallholder farmers due to limited financial resources, knowledge of, and access to herbicides. Weed control, although a major challenge in the initial years of conversion to CA, can be managed by a suite of options in reach of smallholder farmers. The level and extent of their application and the specific combination of weed control option used depend on the agroecology and the socioeconomic circumstances of the farmers to whom the different options have to be adapted.

Once weed-related challenges in the first years of conversion to CA are under control, weed pressure usually declines, thereby making its continuation easier for smallholder farmers. Nevertheless, successful weed control is not possible without farmers maintaining CA principles and practices in the long term. Adopting CA requires farmers to change the way they treat their land and habits that have been passed on for generations; otherwise, the benefits cannot be realized. Farmers therefore need to be supported to adopt proper weed management strategies, such as preventing weeds from setting seeds, ensuring that crop residue cover is retained, and systematically using rotations or intercropping with competitive crop species. Finding locally adapted weed management practices and supporting their adoption will allow farmers to reap the potential benefits of $\mathrm{CA}$, which may improve their resiliency to different stresses in the long term.

Acknowledgements We would like to thank Alexander Schöning of the Deutsche Gesellschaft für Internationale Zusammenarbeit (GIZ) for valuable suggestions and inputs that have enriched this study. Sang eun Bae of Universität Hohenheim is acknowledged for her support in preliminary research. This study has been embedded into the CGIAR Research Program MAIZE, Flagship Sustainable intensification of smallholder farming systems.

Funding information We acknowledge the CGIAR Fund Council, Australia (ACIAR), Irish Aid, European Union, International Fund for Agriculture Development (IFAD), Netherlands, New Zealand, Switzerland, UK, USAID and Thailand for funding to the CGIAR Research Program MAIZE for supporting the time of Christian Thierfelder to participate in this study.

\section{References}

Anderson RL (2015) Integrating a complex rotation with no-till improves weed management in organic farming. A review. Agron Sustain Dev 35:967-974. https://doi.org/10.1007/s13593-015-0292-3

Andersson JA, D'Souza S (2014) From adoption claims to understanding farmers and contexts: a literature review of conservation agriculture (CA) adoption among smallholder farmers in southern Africa. Agric Ecosyst Environ 187:116-132. https:// doi.org/10.1016/j.agee.2013.08.008

Arias-Estévez M, López-Periago E, Martínez-Carballo E, Simal-Gándara J, Mejuto JC, García-Río L (2008) The mobility and degradation of pesticides in soils and the pollution of groundwater resources. Agric Ecosyst Environ 123(4):247-260. https://doi.org/10.1016/j.agee. 2007.07.011

Arslan A, McCarthy N, Lipper L, Asfaw S, Cattaneo A (2014) Adoption and intensity of adoption of conservation farming practices in Zambia. Agric Ecosyst Environ 187:72-86. https://doi.org/10. 1016/j.agee.2013.08.017

Ascard J (1995) Effects of flame weeding on weed species at different developmental stages. Weed Res 35:398-411. https://doi.org/10. 1111/j.1365-3180.1995.tb01636.x

Ascard J, Hatcher PE, Melander B, Upadhyaya MK (2007) Thermal weed control. In: Upadhyaya MK, Blackshaw RE (eds) Nonchemical weed management: principles, concepts and technology. Swedish Board of Agriculture, Alnarp, 155-177. https://doi.org/10. 1079/9781845932909.0155

Bajwa AA (2014) Sustainable weed management in conservation agriculture. Crop Prot 65:105-113. https://doi.org/10.1016/j.cropro. 2014.07.014

Bàrberi P, Lo Cascio B (2001) Long-term tillage and crop rotation effects on weed seedbank size and composition. Weed Res 41(4):325-340. https://doi.org/10.1046/j.1365-3180.2001.00241.x

Baudron F, Sims B, Justice S, Kahan DG, Rose R, Mkomwa S et al (2015a) Re-examining appropriate mechanization in Eastern and Southern Africa: two-wheel tractors, conservation agriculture, and private sector involvement. Food Secur 7(4):889-904

Baudron F, Thierfelder C, Nyagumbo I, Gérard B (2015b) Where to target conservation agriculture for African smallholders? How to overcome challenges associated with its implementation? Experience 
from Eastern and Southern Africa. Environments 2(3):338-357. https://doi.org/10.3390/environments2030338

Bishop-Sambrook C (2003) Labour saving technologies and practices for farming and household activities in Eastern and Southern Africa. Labour constraints and the impact of HIV/AIDS on rural livelihoods in Bondo and Busia Districts, Western Kenya. IFAD/FAO, Rome

Blackshaw RE, Harker KN, O’Donovan JT, Beckie HJ, Smith EG (2008) Ongoing development of integrated weed management systems on the Canadian prairies. Weed Sci 56(1):146-150. https://doi.org/10. 1614/WS-07-038.1

Bond (2002) In:Naylor REL (ed)Weed management handbook 9th edn. Oxford: Blackwell Science Ltd, 280-293

Brady N, Weil R (2010) Elements of the nature and property of soils, 3rd edn. Pearson Education Unlimited, Harlow

Carlson J (2008) Intercropping with maize in sub-arid regions. Community planning \& analysis. Retrieved from http://forest.mtu. edu/pcforestry/resources/studentprojects/Maize Intercropping in East Africa.pdf

Carruthers K, Fe Q, Cloutier D, Smith DL (1998) Intercropping corn with soybean, lupin and forages: weed control by intercrops combined with interrow cultivation. Eur J Agron 8(3-4):225-238. https://doi. org/10.1016/S1161-0301(97)00062-2

Carter MR, Ivany JA (2006) Weed seed bank composition under three long-term tillage regimes on a fine sandy loam in Atlantic Canada. Soil Tillage Res 90:29-38. https://doi.org/10.1016/j.still.2005.08.002

Challinor A, Wheeler T, Garforth C, Craufurd P, Kassam A (2007) Assessing the vulnerability of food crop systems in Africa to climate change. Clim Chang 83(3):381-399. https://doi.org/10.1007/ s10584-007-9249-0

Chauhan BS, Gill GS, Preston CB (2006) Tillage system effects on weed ecology, herbicide activity and persistence: a review. Aust J Exp Agric 46:1557-1570. https://doi.org/10.1071/EA05291

Chauhan BS, Singh RG, Mahajan G (2012) Ecology and management of weeds under conservation agriculture: a review. Crop Prot 38:5765. https://doi.org/10.1016/j.cropro.2012.03.010

Cheesman S, Thierfelder C, Eash NS, Kassie GT, Frossard E (2016) Soil carbon stocks in conservation agriculture systems of Southern Africa. Soil Tillage Res 156:99-109. https://doi.org/10.1016/j.still. 2015.09.018

Chivinge OE (1988) A weed survey of arable lands of the small-scale farming sector of Zimbabwe. Zambeztia 15(2):167-179

Christoffoleti PJ, de Carvalho SJP, López-Ovejero RF, Nicolai M, Hidalgo E, da Silva JE (2007) Conservation of natural resources in Brazilian agriculture: implications on weed biology and management. Crop Prot 26(3):383-389. https://doi.org/10.1016/j.cropro. 2005.06.013

Coello J, Coll L, Piqué M (2017) Can bioplastic or woodchip groundcover replace herbicides or plastic mulching for valuable broadleaf plantations in Mediterranean areas? New For 48:415 429. https://doi.org/10.1007/s11056-017-9567-7

D'Emden FH, Llewellyn RS, Burton MP (2006) Adoption of conservation tillage in Australian cropping regions: an application of duration analysis. Technol Forecase Soc 73:630-647. https://doi.org/10. 1016/j.techfore.2005.07.003

D'Emden FH, Llewellyn RS, Burton MP (2008) Factors influencing adoption of conservation tillage in Australian cropping regions. Aust J Agric Resour Econ 52:169-182. https://doi.org/10.1111/j. 1467-8489.2008.00409.x

Daniell JW, Chappell WE, Couch HB (1969) Effect of sublethal and lethal temperatures on plant cells. Plant Physiol 44:1684-1689. https://doi.org/10.1104/pp.44.12.1684

Dayan FE, Rimando AM, Pan Z, Baerson SR, Gimsing AL, Duke SO (2010) Sorgoleone. Phytochemistry 71(10):1032-1039. https://doi. org/10.1016/j.phytochem.2010.03.011

Demjanová E, Macák M, Ĉaloviü I, Majerník F, Týr Š, Smatana J (2009) Effects of tillage systems and crop rotation on weed density, weed species composition and weed biomass in maize. Agron Res 7(2): 785-792

Di Tomaso JM (1995) Approaches for improving crop competitiveness through the manipulation of fertilization strategies. Weed Sci 43(3): 491-497

Dowswell CR, Paliwal RL, Cantell RP (1996) Maize in the third world. Westview Press, Colorado

Ekboir JM (2003) Research and technology policies in innovation systems: Zero tillage in Brazil. Res Pol 32(4):573-586. https://doi.org/ 10.1016/S0048-7333(02)00058-6

Elsgaard L, Joergensen MH, Elmholt S (2010) Effects of band-steaming on microbial activity and abundance in organic farming soil. Agric Ecosyst Environ 137:223-230. https://doi.org/10.1016/j.agee.2010. 02.007

Erasmo EAL, Azevedo WR, Sarmento RA, Cunha AM, Garcia SLR (2004) Potencial de espécies utilizadas como adubo verde no manejo integrado de plantas daninhas. Planta Daninha 22(3):337342. https://doi.org/10.1590/S0100-83582004000300002

Erenstein O (2003) Smallholder conservation farming in the tropics and sub-tropics: a guide to the development and dissemination of mulching with crop residues and cover crops. Agric Ecosyst Environ 100(1-3):17-37. https://doi.org/10.1016/S0167-8809(03) 00150-6

FAO (2002) Conservation agriculture: case studies in Latin America and Africa. FAO Soils Bulletin 78 FAO, Rome

Flower KC, Cordingley N, Ward PR, Weeks C (2012) Nitrogen, weed management and economics with cover crops in conservation agriculture in a Mediterranean climate. Field Crops Res 132:63-75. https://doi.org/10.1016/j.fcr.2011.09.011

Gatere L, Lehmann J, DeGloria S, Hobbs P, Delve R, Travis A (2013) One size does not fit all: conservation farming success in Africa more dependent on management than on location. Agric Ecosyst Environ 179:200-207. https://doi.org/10.1016/j.agee.2013.08.006

Gianessi L, Bruce T, Foyer C, Halford N, Keys A, Kunert K, et al (2009) Solving Africa's weed problem: increasing crop production \& improving the lives of women. Proceedings of "Agriculture: Africa's engine for growth-plant science and biotechnology hold the key", 9-23

Giller KE, Witter E, Corbeels M, Tittonell P (2009) Conservation agriculture and smallholder farming in Africa: the heretics' view. Field Crops Res 114(1):23-34. https://doi.org/10.1016/j.fcr.2009.06.017

Glenn S, Angle JS (1987) Atrazine and simazine in runoff from conventional and no-till corn watersheds. Agric Ecosyst Environ 18:273-280

Govaerts B, Verhulst N, Castellanos-Navarrete A, Sayre KD, Dixon J, Dendooven L (2009) Conservation agriculture and soil carbon sequestration: between myth and farmer reality. Crit Rev Plant Sci 28(3):97-122. https://doi.org/10.1080/07352680902776358

Graham P, Vance C (2003) Legumes: Importance and constraints to greater use. Plant Physiol 131(3):872-877

Haggblade S, Tembo G (2003) Development, diffusion and impact of conservation farming. FSRP Working Paper No 8(8): 1-63

Hobbs P, Sayre K, Gupta R (2008) The role of conservation agriculture in sustainable agriculture. Philos Trans R Soc B: Biol Sci 363(1491): 543-555. https://doi.org/10.1098/rstb.2007.2169

Iqbal J, Cheema ZA, An M (2007) Intercropping of field crops in cotton for the management of purple nutsedge (Cyperus rotundus L.) Plant Soil 300(1-2):163-171. https://doi.org/10.1007/s11104-007-9400-8

Jat R, Sahrawat K, Kassam A (2013) Conservation agriculture: global prospects and challenges. https://doi.org/10.1079/9781780642598. 0000

Johansen C, Haque ME, Bell RW, Thierfelder C, Esdaile RJ (2012) Conservation agriculture for small holder rainfed farming: opportunities and constraints of new mechanized seeding systems. Field Crops Res 132:18-32. https://doi.org/10.1016/j.fcr.2011.11.026

Johnson WC, Davis RF, Mullinix BG (2007) An integrated system of summer solarization and fallow tillage for Cyperus esculentus and 
nematode management in the southeastern coastal plain. Crop Prot 26(11):1660-1666. https://doi.org/10.1016/j.cropro.2007.02.005

Kabambe VH, Kanampiu F, Ngwira A (2008) Imazapyr (herbicide) seed dressing increases yield, suppresses Striga asiatica and has seed depletion role in maize (Zea mays L.) in Malawi. Afr J Biotechnol 7(18):3293-3298 ST-Imazapyr (herbicide) seed dressing

Kanampiu FK, Kabambe V, Massawe C, Jasi L, Friesen D, Ransom JK, Gressel J (2003) Multi-site, multi-season field tests demonstrate that herbicide seed-coating herbicide-resistance maize controls Striga spp. and increases yields in several African countries. Crop Prot 22(5):697-706. https://doi.org/10.1016/S0261-2194(03)00007-3

Kassam A, Friedrich T, Derpsch R, Kienzle J (2015) Overview of the worldwide spread of conservation agriculture. Field actions science reports. J Field Actions 8:1-10

Kent R, Johnson D, Becker M (2001) The influence of cropping system on weed communities of rice in Cote d'Ivoire, West Africa. Agric Ecosyst Environ 87(3):299-307. https://doi.org/10.1016/S01678809(01)00153-0

Kirkegaard JA, Conyers MK, Hunt JR, Kirkby CA, Watt M, Rebetzke GJ (2014) Sense and nonsense in conservation agriculture: principles, pragmatism and productivity in Australian mixed farming systems. Agric Ecosyst Environ 187:133-145. https://doi.org/10.1016/j.agee. 2013.08.011

Koch BA (2010) Damage caused by genetically modified organisms: comparative survey of redress options for harm to persons, property or the environment. Walter de Guyter, Germany

Kolberg RL, Wiles LJ (2002) Effect of steam application on cropland weeds. Weed Technol 16(1):43-49. https://doi.org/10.1614/0890037X(2002)016[0043:EOSAOC]2.0.CO;2

Kolpin DW, Thurman EM, Linhart SM (1998) The environmental occurrence of herbicides: the importance of degradates in ground water. Arch Environ Contam Toxicol 35(3):385-390. https://doi.org/10. 1016/S0048-9697(99)00535-5

Kumar V, Singh S, Chhokar RS, Malik RK, Brainard DC, Ladha JK (2013) Weed management strategies to reduce herbicide use in zero-till rice-wheat cropping systems of the indo-gangetic plains. Weed Technol 27(1):241-254. https://doi.org/10.1614/WT-D-1200069.1

Lahmar R, Triomphe B (2007) Conservation agriculture for sustainable land management to improve the livelihood of people in dry areas. In: Proceedings of the international workshop on conservation agriculture for sustainable land management to improve the livelihood of people in dry areas, ACSAD and GTZ, Damascus, 7-9 May 2007, pp 123-141

Lahmar R, Bationo BA, Dan Lamso N, Guéro Y, Tittonell P (2012) Tailoring conservation agriculture technologies to West Africa semi-arid zones: building on traditional local practices for soil restoration. Field Crops Res 132:158-167. https://doi.org/10.1016/j. fcr.2011.09.013

Lenssen AW (2008) Planting date and preplant weed management influence yield, water use, and weed seed production in herbicide-free forage barley. Weed Technol 22(3):486-492. https://doi.org/10. 1614/WT-08-009.1

Liebl RA, Simmons FW, Wax LM, Stoller EW (1992) Effect of rye (Secale cereale) mulch on weed control and soil moisture in soybean (Glycine max). Weed Technol 6:838-846

Liebman M, Davis AS (2000) Integration of soil, crop and weed management in low-external-input farming systems. Weed Res 40(1): 27-47. https://doi.org/10.1046/j.1365-3180.2000.00164.x

Little AD (2010) Technology brief-seed coating. In: ISHA technology briefs: Innovations in soil health for Sub-Saharan Africa. Meridian Institute, Washington, DC, pp 1-24

Llewellyn RS, D'Emden FH, Kuehne G (2012) Extensive use of notillage in grain growing regions of Australia. Field Crops Res 132: 204-212. https://doi.org/10.1016/j.fcr.2012.03.013
Locke MA, Zablotowicz RM, Reddy KN, Steinriede RW (2008) Tillage management to mitigate herbicide loss in runoff under simulated rainfall conditions. Chemosphere 70:1422-1428. https://doi.org/ 10.1016/j.chemosphere.2007.09.006

Mafongoya PL, Bationo A, Kihara J, Waswa BS (2006) Appropriate technologies to replenish soil fertility in southern Africa. Nutri Cycl Agroecosyst 76(2-3):137-151. https://doi.org/10.1007/ s10705-006-9049-3

Mafongoya PL, Rusinamhodzi L, Siziba S, Thierfelder C, Mvumi BM, Nhau B et al (2016) Maize productivity and profitability in conservation agriculture systems across agro-ecological regions in Zimbabwe: a review of knowledge and practice. Agric Ecosyst Environ 220:211-225. https://doi.org/10.1016/j.agee.2016.01.017

Mandumbu R, Jowah P, Karavina C, Tibugari H (2011) Integrated weed management in Zimbabwe's smallholder sector, where are we?: a review. Mod Appl Sci 5(5):111-117. https://doi.org/10.5539/mas. v5n5p 111

Mangin AR, Hall LM, Schoenau JJ, Beckie HJ (2016) Influence of tillage on control of wild oat (Avena fatua) by the soil-applied herbicide pyroxasulfone. Weed Sci 65(2):266-274. https://doi.org/10.1017/ wsc. 2016.22

Marín C, Weiner J (2014) Effects of density and sowing pattern on weed suppression and grain yield in three varieties of maize under high weed pressure. Weed Res 54:467-474

Mashingaidze N, Twomlow SJ, Hove L (2009a) Crop and weed responses to residue retention and method of weeding in first two years of a hoe-based minimum tillage system in semi-arid Zimbabwe. J SAT Agric Res 7:1-11

Mashingaidze AB, van der Werf W, Lotz LAP, Chipomho J, Kropff MJ (2009b) Narrow rows reduce biomass and seed production of weeds and increase maize yield. Ann Appl Biol 155:207-218. https://doi. org/10.1111/j.1744-7348.2009.00331.x

Mashingaidze N, Madakadze C, Twomlow S, Nyamangara J, Hove L (2012) Crop yield and weed growth under conservation agriculture in semi-arid Zimbabwe. Soil Tillage Res 124:102-110. https://doi. org/10.1016/j.still.2012.05.008

Mavunganidze Z, Madakadze IC, Nyamangara J, Mafongoya P (2014) The impact of tillage system and herbicides on weed density, diversity and yield of cotton (Gossipium hirsutum L.) and maize (Zea mays L.) under the smallholder sector. Crop Prot 58:25-32. https:// doi.org/10.1016/j.cropro.2013.12.024

Mazvimavi K, Twomlow S (2009) Socioeconomic and institutional factors influencing adoption of conservation farming by vulnerable households in Zimbabwe. Agric Syst 101(1-2):20-29. https://doi. org/10.1016/j.agsy.2009.02.002

Mazvimavi K, Ndlovu PV, Nyathi P, Minde IJ (2010) Conservation agriculture practices and adoption by smallholder farmers in Zimbabwe. Poster presented at the joint 3rd African Association of Agricultural Economists (AAAE) and 48th Agricultural Economists Association of South Africa (AEASA) conference, Cape Town, 1923 September 2010

Melander B, Kristensen JK (2011) Soil steaming effects on weed seedling emergence under the influence of soil type, soil moisture, soil structure and heat duration. Ann Appl Biol 158:194-203. https://oi.org/ 10.1111/j.1744-7348.2010.00453.x

Melander B, Munier-Jolain N, Charles R, Wirth J, van der Weide R, Bonin L et al (2013) European perspectives on the adoption of nonchemical weed management in reduced-tillage systems for arable crops. Weed Technol 27(1):231-240. https://doi.org/10.1614/ WT-D-12-00066.1

Mhlanga B, Cheesman S, Maasdorp B, Muoni T, Mabasa S, Mangosho E, Thierfelder C (2015a) Weed community responses to rotations with cover crops in maize-based conservation agriculture systems of Zimbabwe. Crop Prot 69:1-8. https://doi.org/10.1016/j.cropro. 2014.11.010 
Mhlanga B, Cheesman S, Maasdorp B, Mupangwa W, Thierfelder C (2015b) Contribution of cover crops to the productivity of maizebased conservation agriculture systems in Zimbabwe. Crop Sci 55(4):1791-1805. https://doi.org/10.2135/cropsci2014.11.0796

Mhlanga B, Chauhan BS, Thierfelder C (2016a) Weed management in maize using crop competition: a review. Crop Prot 88:28-36. https:// doi.org/10.1016/j.cropro.2016.04.019

Mhlanga B, Cheesman S, Chauhan BS, Thierfelder C (2016b) Weed emergence as affected by maize (Zea mays L.)-cover crop rotations in contrasting arable soils of Zimbabwe under conservation agriculture. Crop Prot 81:47-56. https://doi.org/10.1016/j.cropro.2015.12. 007

Micheni A, Mburu D, Kanampiu F, Mugai N, Kihanda F (2014) Glyphosate-based herbicides on weeds management and maize performance under conservation agriculture practices in eastern Kenya. Int J Agric Res Gov Ecol 10(3):257-268

Midega CAO, Salifu D, Bruce TJ, Pittchar J, Pickett JA, Khan ZR (2014) Cumulative effects and economic benefits of intercropping maize with food legumes on Striga Hermonthica infestation. Field Crops Res 155:144-152. https://doi.org/10.1016/j.fcr.2013.09.012

Midega CAO, Wasonga CJ, Hooper AM, Pickett JA, Khan ZR (2017) Drought-tolerant Desmodium species effectively suppress parasitic striga weed and improve cereal grain yields in western Kenya. Crop Prot 98:94-101. https://doi.org/10.1016/j.cropro.2017.03.018

Mkamilo GS (2004) Maize-sesame intercropping in Southeast Tanzania: farmers' practices and perceptions, and intercrop performance. $\mathrm{PhD}$ Dissertation, Wageningen University, the Netherlands, 1-112

Moyer JR, Roman ES, Lindwall CW, Blackshaw RE (1994) Weed management in conservation tillage systems for wheat production in North and South America. Crop Prot 13(4):243-259. https://doi. org/10.1016/0261-2194(94)90012-4

Mtambanengwe F, Nezomba H, Tauro T, Chagumaira C, Manzeke MG, Mapfumo P (2015) Mulching and fertilization effects on weed dynamics under conservation agriculture-based maize cropping in Zimbabwe. Environments 2:399-414. https://doi.org/10.3390/ environments 2030399

Muoni T, Mhlanga B (2014) Weed management in Zimbabwean smallholder conservation agriculture farming sector. Asian J Agric Rural Dev 4(3):267-276

Muoni T, Rusinamhodzi L, Thierfelder C (2013) Weed control in conservation agriculture systems of Zimbabwe: identifying economical best strategies. Crop Prot 53:23-28. https://doi.org/10.1016/j. cropro.2013.06.002

Muoni T, Rusinamhodzi L, Rugare JT, Mabasa S, Mangosho E, Mupangwa W, Thierfelder C (2014) Effect of herbicide application on weed flora under conservation agriculture in Zimbabwe. Crop Prot 66:1-7. https://doi.org/10.1016/j.cropro.2014.08.008

Mupangwa W, Thierfelder C (2015) Common weed species and their chemical control in conservation agriculture (CA) systems. CIMMYT. Series: Technical bulletin, Harare, Zimbabwe, 1-2

Mupangwa W, Walker S, Masvaya E, Magombeyi M, Munguambe P (2016) Rainfall risk and the potential of reduced tillage systems to conserve soil water in semi-arid cropping systems of southern Africa. AIMS Agric Food 1(1):85-101. https://doi.org/10.3934/ agrfood.2016.1.85

Mwangi HW, Kihurani AW, Wesonga JM, Ariga ES, Kanampiu F (2015) Effect of Lablab purpureus L. cover crop and imidazolinone resistant (IR) maize on weeds in drought prone areas, Kenya. Crop Prot 72:36-40. https://doi.org/10.1016/j.cropro.2015.02.013

Najafi B, Torabi Dastgerduei S (2015) Optimization of machinery use on farms with emphasis on timeliness costs. J Agric Sci Technol 17(3): 533-541

Nakamoto T, Yamagishi J, Miura F (2006) Effect of reduced tillage on weeds and soil organisms in winter wheat and summer maize cropping on humic andosols in Central Japan. Soil Tillage Res 85(1-2):94-106. https://doi.org/10.1016/j.still.2004.12.004
Naylor REL, Lutman PJ (2002) In:Naylor REL (ed) Weed management handbook 9th edn. Oxford: Blackwell Science Ltd, pp 1-61

Neve P, Diggle AJ, Smith FP, Powles SB (2003) Simulating evolution of glyphosate resistance in Lolium rigidum II: past, present and future glyphosate use in Australian cropping. Weed Res 43:418-427

Ngwira AR (2013) Conservation agriculture systems for smallholder farmers in Malawi: an analysis of agronomic and economic benefits and constraints to adoption. PhD Dissertation, Norwegian University of Life Sciences, Norway, 1-47

Ngwira A, Johnsen FH, Aune JB, Mekuria M, Thierfelder C (2014) Adoption and extent of conservation agriculture practices among smallholder farmers in Malawi. J Soil Water Conserv 69(2):107119. https://doi.org/10.2489/jswc.69.2.107

Norsworthy JK, Ward SM, Shaw DR, Llewellyn RS, Nichols RL, Webster TM et al (2012) Reducing the risks of herbicide resistance: best management practices and recommendations. Weed Sci 60(sp1):31-62. https://doi.org/10.1614/WS-D-11-00155.1

Norsworthy JK, Korres NE, Walsh MJ, Powles SB (2016) Integrating herbicide programs with harvest weed seed control and other fall management practices for the control of glyphosate-resistant palmer Amaranth (Amaranthus palmeri). Weed Sci 64(3):540-550. https:// doi.org/10.1614/WS-D-15-00210.1

Nyamangara J, Mashingaidze N, Masvaya EN, Nyengerai K, Kunzekweguta M, Tirivavi R, Mazvimavi K (2013) Weed growth and labor demand under hand-hoe based reduced tillage in smallholder farmers' fields in Zimbabwe. Agric Ecosyst Environ 187: 146-154. https://doi.org/10.1016/j.agee.2013.10.005

Nyanga PH, Johnsen FH, Kalinda TH (2012) Gendered impacts of conservation agriculture and paradox of herbicide use among smallholder farmers. Int J Technol Dev Stud 3(1):1-24

Odhiambo JA, Norton U, Ashilenje D, Omondi EC, Norton JB (2015) Weed dynamics during transition to conservation agriculture in Western Kenya maize production. PLoS One 10(8):1-13. https:// doi.org/10.1371/journal.pone.0133976

Oswald A, Ransom JK (2001) Striga control and improved farm productivity using crop rotation. Crop Prot 20(2):113-120. https://doi.org/ 10.1016/S0261-2194(00)00063-6

Owen MDK, Zelaya IA (2005) Herbicide-resistant crops and weed resistance to herbicides. Pest Manag Sci 61(3):301-311. https://doi.org/ $10.1002 /$ ps. 1015

Owen MJ, Martinez NJ, Powles SB (2014) Multiple herbicide-resistant Lolium rigidum (annual ryegrass) now dominates across the Western Australian grain belt. European Weed Res Soc 54:314 324. https://doi.org/10.1111/wre. 12068

Radicetti E, Mancinelli R, Campiglia E (2013) Impact of managing cover crop residues on the floristic composition and species diversity of the weed community of pepper crop (Capsicum annuum L.) Crop Prot 44:109-119. https://doi.org/10.1016/j.cropro.2012.10.017

Rasmussen J (2003) Punch planting, flame weeding and stale seedbed for weed control in row crops. Weed Res 43(6):393-403. https://doi. org/10.1046/j.0043-1737.2003.00357.x

Riches CR, Twomlow SJ, Dhliwayo H (1997) Low-input weed management and conservation tillage in semi-arid Zimbabwe. Exp Agric 33: $173-187$

Roozkhosh M, Eslami SV, Al-Ahmadi MJ (2017) Effect of plastic mulch and burial depth on purple nutsedge (Cyperus rotundus) emergence and growth. Arch Agron Soil Sci:1-11. https://doi.org/10.1080/ 03650340.2017.1280782

Rusinamhodzi L, Corbeels M, Van Wijk MT, Rufino MC, Nyamangara J, Giller KE (2011) A meta-analysis of long-term effects of conservation agriculture on maize grain yield under rain-fed conditions. Agron Sustain Dev 31(4):657-673. https://doi.org/10.1007/ s13593-011-0040-2

Sahile G, Abebe G, Abdel-Rahman MA-T (2005) Effect of soil solarization on Orobanche soil seed bank and tomato yield in Central Rift Valley of Ethiopia. World J Agric Sci 1(2):143-147 
Sakala WD, Cadisch G, Giller KE (2000) Interactions between residues of maize and pigeonpea and mineral $\mathrm{N}$ fertilizers during decomposition and $\mathrm{N}$ mineralization. Soil Biol Biochem 32(5):679-688. https://doi.org/10.1016/S0038-0717(99)00204-7

Samtani JB, Ajwa HA, Weber JB, Browne GT, Klose S, Hunzie J, Fennimore SA (2011) Evaluation of non-fumigant alternatives to methyl bromide for weed control and crop yield in California strawberries (Fragaria ananassa L.). Crop Prot 30:45-51. https://doi.org/ 10.1016/j.cropro.2010.08.023

Santín-Montanyá MI, Martín-Lammerding D, Zambrana E, Tenorio JL (2016) Management of weed emergence and weed seed bank in response to different tillage, cropping systems and selected soil properties. Soil Tillage Res 161:38-46. https://doi.org/10.1016/j. still.2016.03.007

Sauer TC, Daniel TJ (1987) Effect of tillage system on runoff losses of surface-applied pesticides. Soil Sci Soc Am J 51:410-415

Shrestha A, Knezevic SZ, Roy RC, Ball-Coelho BR, Swanton CJ (2002) Effect of tillage, cover crop and crop rotation on the composition of weed flora in a sandy soil. Weed Res 42(1):76-87. https://doi.org/ 10.1046/j.1365-3180.2002.00264.x

Sims BG, Bhatti MA, Mkomwa S, Kienzle J (2012a) Development of mechanization options for smallholder farmers: examples of local manufacturing opportunities for sub-Saharan Africa CIGR-AgEng 2012. Special Parallel Conference 08: Creating a competitive edge through agricultural mechanization and post-harvest technology in developing countries. Valencia, Spain, 8-12 June 2012, 1-6

Sims BG, Thierfelder C, Kienzle J, Friedrich T, Kassam A (2012b) Development of the conservation agriculture equipment industry in sub-Saharan Africa. Appl Eng Agric 28(6):813-823. https://doi org/10.13031/2013.42472

Simunji S, Mbewe D, Munyinda K, Muliokela W, Moono D (2011) Evaluation of maize (Zea mays. L)- Cowpea (Vigna unguiculata. L) intercropping system for improved weed management and land use. University of Zambia, Lusaka, pp 1-20

Siziba S (2007) Assessing the adoption of conservation agriculture in Zimbabwe's smallholder sector PhD Dissertation. University of Hohenheim, Germany, 1-174

Smaling EMA, Janssen BH (1997) Soil fertility in Africa is at stake. In: Buresh RJ, Sanchez PA, Calhoun F (eds) Replenishing soil fertility in Africa. SSSA, American Society of Agronomy, Madison, 47-61

Stapleton JJ (2000) Soil solarization in various agricultural production systems. Crop Prot 19(8-10):837-841. https://doi.org/10.1016/ S0261-2194(00)00111-3

Stapleton JJ, DeVay JE (1986) Soil solarization: a non-chemical approach for management of plant pathogens and pests. Crop Prot 5(3):190 198. https://doi.org/10.1016/0261-2194(86)90101-8

Stepanovic S, Datta A, Neilson B, Bruening C, Shapiro CA, Gogos G, Knezevic SZ (2015) Effectiveness of flame weeding and cultivation for weed control in organic maize. Biol Agric Hort 8765:1-16. https://doi.org/10.1080/01448765.2015.1028443

Stokstad E (2013) The war against weeds down under. Science 341(6147):734-736

Swanton CJ, Shrestha A, Knezevic SZ, Roy RC, Ball-Coelho BR (2000) Influence of tillage type on vertical weed seedbank distribution in a sandy soil. C J of Plant Sci 80:455-457. https://doi.org/10.4141/P99-020

Swenson S, Moore KM (2009) Developing conservation agriculture production systems: an analysis of local networks. Sustainable agriculture and natural resource management collaborative research support program, Moore, (10), 1-46. Retrieved from file://Users/ DURU/Documents/MendeleyDesktop/Swenson, Tech-2009Developing Conservation Agriculture Production Systems An Analysis of Local Networks.pdf

Syakalima M, Choongo K, Mwenechany R, Wepener V, Yamasaki M, Yoshimitsu M (2006) Pesticide/herbicide pollutants in the Kafue river and a preliminary investigation into their biological effect through catalase levels in fish. Jpn J Vet Res 54(2):119-128
Teasdale JR, Beste CE, Potts WE (1991) Response of weeds to tillage and cover crop residue. Weed Sci 39(2):195-199

Theisen G, Bastiaans L (2015) Low disturbance seeding suppresses weeds in no-tillage soyabean. Weed Res 55:598-608. https://doi. org/10.1111/wre.12176

Thierfelder C, Wall PC (2009) Effects of conservation agriculture techniques on infiltration and soil water content in Zambia and Zimbabwe. Soil Tillage Res 105(2):217-227. https://doi.org/10. 1016/j.still.2009.07.007

Thierfelder C, Wall PC (2010a) Investigating conservation agriculture (CA) Systems in Zambia and Zimbabwe to mitigate future effects of climate change. J Crop Improv 24(2):113-121. https://doi.org/10. 1080/15427520903558484

Thierfelder C, Wall PC (2010b) Rotation in conservation agriculture systems of Zambia: effects on soil quality and water relations. Exp Agric 46(3):309-325. https://doi.org/10.1017/ S001447971000030X

Thierfelder C, Wall PC (2015). Weed control in conservation agriculture. CIMMYT, 1-2. Retrieved from http://dev.intechweb.org/books/ show/title/herbicides-theory-and-applications

Thierfelder C, Cheesman S, Rusinamhodzi L (2012a) A comparative analysis of conservation agriculture systems: benefits and challenges of rotations and intercropping in Zimbabwe. Field Crops Res 137: 237-250. https://doi.org/10.1016/j.fcr.2012.08.017

Thierfelder C, Mwila M, Rusinamhodzi L (2012b) Conservation agriculture in eastern and southern provinces of Zambia: long term effects on soil quality and maize productivity. Soil Tillage Res 126:246-258

Thierfelder C, Rusinamhodzi L, Ngwira AR, Mupangwa W, Nyagumbo I, Kassie GT, Cairns JE (2014) Conservation agriculture in Southern Africa: advances in knowledge. Renew Agric Food Syst 30(4):1-21. https://oi.org/10.1017/S1742170513000550

Thierfelder C, Matemba-Mutasa R, Rusinamhodzi L (2015) Yield response of maize (Zea Mays L.) to conservation agriculture cropping system in Southern Africa. Soil Tillage Res 146(PB):230-242. https://doi.org/10.1016/j.still.2014.10.015

Thierfelder C, Bunderson WT, Jere ZD, Mutenje M, Ngwira AR (2016a) Development of conservation agriculture (CA) Systems in Malawi: lessons learned from 2005 to 2005. Exp Agric 52(4):579-604. https://doi.org/10.1017/S0014479715000265

Thierfelder C, Matemba-Mutasa R, Bunderson WT, Mutenje M, Nyagumbo I, Mupangwa W (2016b) Evaluating manual conservation agriculture systems in southern Africa. Agric Ecosyst Environ 222:112-124. https://doi.org/10.1016/j.agee.2016.02.009

Thierfelder C, Chivenge P, Mupangwa W, Rosenstock TS, Lamanna C, Eyre JX (2017) How climate-smart is conservation agriculture (CA)? - its potential to deliver on adaptation, mitigation and productivity on smallholder farms in Southern Africa. Food Secur, in press

Tittonell P, Vanlauwe B, Leffelaar PA, Rowe EC, Giller KE (2005) Exploring diversity in soil fertility management of smallholder farms in western Kenya: I. Heterogeneity at region and farm scale. Agric Ecosyst Environ 110(3-4):149-165. https://doi.org/10.1016/j. agee.2005.04.001

Tittonell P, Scopel E, Andrieu N, Posthumus H, Mapfumo P, Corbeels M et al (2012) Agroecology-based aggradation-conservation agriculture (ABACO): targeting innovations to combat soil degradation and food insecurity in semi-arid Africa. Field Crops Res 132:168 174. https://doi.org/10.1016/j.fcr.2011.12.011

Tollenaar M, Nissanka SP, Aguilera A, Weise SF, Swanton CJ (1994) Effect of weed interference and soil nitrogen on four maize hybrids. Agron J 86:596-601. https://doi.org/10.2134/agronj1994. 00021962008600040004x

Twomlow S, O’Neill D (2003) An analysis of smallholder crop production in southern Africa. In: Beukes et al (eds) Proceedings of the symposium and workshop on water conservation technologies for sustainable agriculture in sub-Saharan Africa (WCT). Bloemfontein, South Africa 81-91. https://doi.org/10.13140/2.1.3168.3844 
Umar BB, Aune JB, Johnsen FH, Lungu IO (2012) Are smallholder Zambian farmers economists? A dual-analysis of farmers' expenditure in conservation and conventional agriculture systems. J Sust Agric 36(8):908929. https://doi.org/10.1080/10440046.2012.661700

Valbuena D, Erenstein O, Homann-Kee Tui S, Abdoulaye T, Claessens L, Duncan AJ et al (2012) Conservation agriculture in mixed croplivestock systems: scoping crop residue trade-offs in sub-Saharan Africa and South Asia. Field Crops Res 132:175-184. https://doi. org/10.1016/j.fcr.2012.02.022

Vanlauwe B, Wendt J, Giller KE, Corbeels M, Gerard B, Nolte C (2014) A fourth principle is required to define conservation agriculture in subSaharan Africa: the appropriate use of fertilizer to enhance crop productivity. Field Crops Res. https://doi.org/10.1016/j.fcr.2013.10.002

Vogel H (1994) Weeds in single-crop conservation farming in Zimbabwe. Soil Tillage Res 31(2-3):169-185. https://doi.org/10.1016/01671987(94)90078-7

Walker RH, Buchanan GA (1982) Crop manipulation in integrated weed management systems. Weed Sci 30(1):17-24
Wall P (2007) Tailoring conservation agriculture to the needs of small farmers in developing countries. J Crop Improv 19:137-155. https:// doi.org/10.1300/J411v19n01

Wall P, Thierfelder C, Ngwira A (2014). Conservation agriculture in Eastern and Southern Africa. Conservation agriculture: global prospects and challenges, 1-22. Retrieved from http://www.cabdirect. org/abstracts/20133423257.html

Walsh M, Newman P, Powles S (2013) Targeting weed seeds in-crop: a new weed control paradigm for global agriculture. Weed Technol 27:431-436. https://doi.org/10.1614/WT-D-12-00181.1

Zegada-Lizarazu W, Kanyomeka L, Izumi Y, Iijima M (2006) Pearl millet developed deep roots and changed water sources by competition with intercropped cowpea in the semiarid environment of northern Namibia. Plant Prod Sci 9(4):355-363. https://doi.org/10.1626/pps.9.355

Zimdahl RL (1993) Fundamentals of weed Sci. Academic Press, New York 